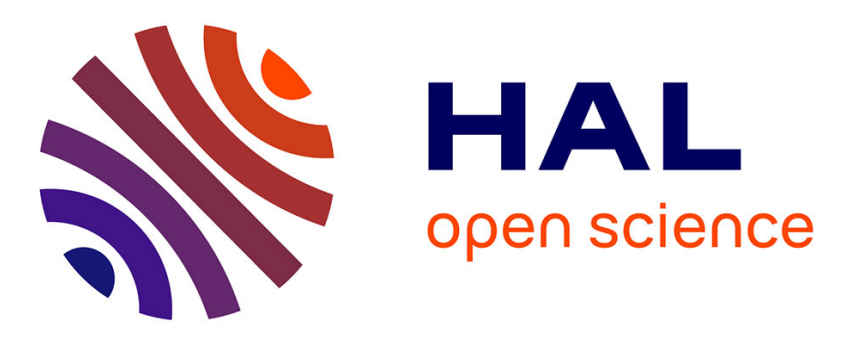

\title{
Massively Introduced Managed Species and Their Consequences for Plant-Pollinator Interactions
}

Benoît Geslin, Benoit Gauzens, Mathilde Baude, Isabelle Dajoz, Colin Fontaine, Mickaël Henry, Lise Ropars, Orianne Rollin, Elisa Thébault, Nicolas J. Vereecken

\section{To cite this version:}

Benoît Geslin, Benoit Gauzens, Mathilde Baude, Isabelle Dajoz, Colin Fontaine, et al.. Massively Introduced Managed Species and Their Consequences for Plant-Pollinator Interactions. Advances in Ecological Research, 2017, 57, pp.147-199. 10.1016/bs.aecr.2016.10.007 . hal-01497637

\section{HAL Id: hal-01497637 https://hal.science/hal-01497637}

Submitted on 26 Jun 2018

HAL is a multi-disciplinary open access archive for the deposit and dissemination of scientific research documents, whether they are published or not. The documents may come from teaching and research institutions in France or abroad, or from public or private research centers.
L'archive ouverte pluridisciplinaire HAL, est destinée au dépôt et à la diffusion de documents scientifiques de niveau recherche, publiés ou non, émanant des établissements d'enseignement et de recherche français ou étrangers, des laboratoires publics ou privés. 


\title{
Massively Introduced Managed Species and Their Consequences for Plant-Pollinator Interactions
}

\author{
B. Geslin*, ${ }^{*}$, B. Gauzens ${ }^{\dagger}$, M. Baude ${ }^{\star}$ I. Dajoz ${ }^{\S}$, C. Fontaine ${ }^{\text {II }}$, M. Henry", \\ L. Ropars ${ }^{* \S}$, O. Rollin ${ }^{\#, * *}$, E. Thébault ${ }^{\S}$, N.J. Vereecken ${ }^{\dagger+}$ \\ *Institut Méditerranéen de Biodiversité et d'Ecologie marine et continentale (IMBE-UMR-CNRS-IRD \\ 7263), Equipe Ecologie de la Conservation et Interactions Biotiques, Aix Marseille Univ, Univ Avignon, \\ CNRS, IRD, IMBE, Marseille, France \\ ${ }^{\dagger}$ German Centre for Integrative Biodiversity Research (iDiv) Halle-Jena-Leipzig, Leipzig, Germany \\ *Laboratoire Biologie des Ligneux et des Grandes Cultures (EA 1207), Equipe entomologie et biologie intégrée, \\ Université d'Orléans, Orléans, France \\ ${ }^{\S}$ Institut d'écologie et des sciences de l'environnement de Paris (iEES-Paris UMR CNRS 7618), Equipe \\ Ecologie et évolution des réseaux d'interactions, Université Paris-Diderot-CNRS-UPMC, Paris, France \\ ${ }^{\text {II }}$ Centre d'Ecologie et des Sciences de la Conservation (CESCO UMR CNRS 7204), Equipe Socio- \\ écosystèmes, CNRS-Muséum national d'histoire naturelle, Paris, France \\ "INRA, UR406 Abeilles et Environnement, Avignon, France \\ \#ITSAP-Institut de l'Abeille, Avignon, France \\ ${ }^{*}$ UMT PrADE, Avignon, France \\ ${ }^{+1}$ Agroecology \& Pollination Group, Landscape Ecology \& Plant Production Systems (LEPPS/EIB), Boulevard \\ du Triomphe CP 264/2, Université Libre de Bruxelles (ULB), Brussels, Belgium \\ ${ }^{1}$ Corresponding author: e-mail address: benoit.geslin@imbe.fr
}

\section{Contents}

1. Introduction

2. First Part: Impacts of MIMS in Plant and Pollinator Communities

2.1 The Case of Pollinators

2.2 The Case of Plants

2.3 MIMS as Competitors or Facilitators-Consequences for Communities

3. Second Part: MIMS in Plant-Pollinator Networks

3.1 Impacts of MIMS on the Structure of Plant-Pollinator Networks

3.2 Case Studies of the Position of MIMS in Pollination Webs

3.3 MIMS in Plant-Pollinator Networks: Consequences for Community

Dynamics

4. Conclusion

Acknowledgements

References

\section{Abstract}

Since the rise of agriculture, human populations have domesticated plant and animal species to fulfil their needs. With modern agriculture, a limited number of these species has been massively produced over large areas at high local densities. Like invasive 
species, these Massively Introduced Managed Species (MIMS) integrate local communities and can trigger cascading effects on the structure and functioning of ecosystems. Here, we focus on plant and insect MIMS in the context of plant-pollinator systems. Several crop species such as mass flowering crops (e.g. Brassica napus) and domesticated pollinating insects (e.g. Apis mellifera, Bombus terrestris) have been increasingly introduced worldwide and their impact on natural communities is addressed by an increasing number of scientific studies.

First, we review the impacts of major insect and plant MIMS on natural communities by identifying how they affect other species through competition (direct and apparent competition) or facilitation (attraction, spillover). Second, we show how MIMS can alter the structure of plant-pollinator networks. We specifically analysed the position of A. mellifera from 63 published plant-pollinator webs to illustrate that MIMS can occupy a central position in the networks, leading to functional consequences. Finally, we present the features of MIMS in sensitive environments ranging from oceanic islands to protected areas, as a basis to discuss the impacts of MIMS in urban context and agrosystems. Through the case study of MIMS in plant-pollinator interactions, we thus provide here a first perspective of the role of MIMS in the functioning of ecosystems.

\section{INTRODUCTION}

Since the rise of agriculture, humans have selected and introduced plant and animal species in their environment to cover their needs. A set of species has thus been favoured inside and outside their native geographic ranges. With the agricultural intensification of the 20th century, an unprecedented amplification in the breeding of these species has been observed (Hoekstra and Wiedmann, 2014; MEA, 2005). Here we define as Massively Introduced Managed Species (hereafter MIMS) all plant and animal species introduced voluntarily and abundantly in a given location for agricultural and/or domestic purposes. We specifically focus on MIMS involved in plant-pollinator interactions because of their critical importance for agricultural production but also for native plant reproduction in natural or urban habitats (see Boxes 1-6). Indeed, the cultivated area of pollinator-dependent crops (i.e. Mass Flowering Crops-hereafter MFC) has strongly expanded in relation with the increase in their demand (Aizen and Harder, 2009), notably for human food supply (Eilers et al., 2011), but also for biofuels (Stanley and Stout, 2013). In parallel, the demand for biotic pollination has increased to ensure sufficient MFC yield (Aizen et al., 2008) and this has been amplified with the current worldwide decline of wild pollinators (Goulson et al., 2015; Potts et al., 2010; 


\section{BOX 1 Oceanic Islands}

Most small (several tens to hundreds of $\mathrm{km}^{2}$ ) oceanic islands and archipelagos are areas of exceptional concentration of endemic species (Brooks et al., 2006; Myers et al., 2000). Species communities on islands are usually fragile and sensitive to introductions and invasions (Kaiser-Bunbury et al., 2010, see also Massol et al., 2017). The reported cases of native species extinctions after introduction of alien species on islands are usually due to predation or pathogens rather than exploitative competition (Sax and Gaines, 2008; Sugiura, 2016). Still, exploitative competition with introduced species can reduce the fitness and lead to local extinctions of the native island species, including bees (Sugiura, 2016).

Several cases of exploitative competition for floral resources have been evidenced or suspected in oceanic island systems of various sizes. In the small oceanic Bonin archipelago (Western Pacific, four island groups totalling $106 \mathrm{~km}^{2}$ only), native bees suffered competition with the European honeybee introduced in the 1880s for beekeeping (Kato et al., 1999). Some of them became rare or locally extinct on islands on which managed and feral honeybees became dominant on native flowers, even in well-conserved forest tracts. This was most probably due to an increased competition for nectar and pollen. Given the drastic change of pollination networks in this case study, conservation biologists recommend the removal of managed honeybees and eradication of feral colonies to restore native bee populations.

Similar cases were inferred in other oceanic island systems of various sizes, including the Canary islands for honeybees (Dupont et al., 2004) or Hawaii (Miller et al., 2015)—see also Hansen et al. (2002) for negative effects of introduced honeybees on endemic nectarivorous birds in Mauritius, and KaiserBunbury et al. (2010) for additional insular examples involving introduced bumblebees.

The effects of honeybee introductions on small oceanic islands are, however, difficult to assess due to the lack of suitable control sites without honeybees (Dupont et al., 2004; Hansen et al., 2002). In some insular contexts in which native bees are locally rare or extinct, the introduction of honeybees may help overcome the pollination deficiency of native plants (Hanna et al., 2012), but can also promote the establishment and development of invasive plant populations (Abe et al., 2011).

Vanbergen, 2013). To compensate for the losses of wild pollinators, or lack thereof in intensively managed farmland areas, modern agricultural practices usually rely on massively introduced managed pollinators (mainly Apis mellifera and Bombus spp.) that sometimes become the unique pollinating species of the targeted crops (Cunningham et al., 2016). 


\section{BOX 2 Natural and Protected Habitats}

As outlined by Torné-Noguera et al. (2015), there is currently no specific legislation for the preventive exclusion or limitation of beekeeping activity in most protected areas worldwide. Beekeeping usually conveys the positive image of a traditional breeding activity that contributes to plant community sustainability through pollination. Therefore, some European countries support agrienvironmental schemes (AES) promoting the seasonal introduction of apiaries in "interesting biodiversity areas" through subsidies to beekeepers. Yet, this naïve reasoning may be inappropriate in most situations and should be reevaluated with respect to the context of interest. Protected areas are classified into different categories (e.g. strict nature reserves, Wilderness areas, National parks, Habitat or species management areas; Dudley, 2008), depending on their objectives, history, anthropogenic influence, governance and management, or on the outstanding species diversity or aggregation they hold. The beekeeping innocuousness is unlikely to be supported in the protected areas of highest concern. For instance, 21 apiaries ( 475 colonies) are held in the $32 \mathrm{~km}^{2}$ El Garraf Natural Park, Spain, leading to significant reductions in the pollen and nectar availability, and eventually in the biomass of the native bee community (Torné-Noguera et al., 2015). Authors estimate that native bee communities are likely to be affected at densities beyond 3.5 honeybee colonies per $\mathrm{km}^{2}$. They, however, outline the difficulty to establish consistent recommendations for maximal admissible honeybee colony density given the highly heterogeneous nature of floral resource carrying capacity in space and time. Similarly, Shavit et al. (2009) found significant decreases of native bee flower visitation rates, at local scales, when introducing ten honeybee colonies in two Israelian Natural Parks of a few $\mathrm{km}^{2}$. They highlighted the possible aggravation of competition outcomes during drought years and seasonal food scarcity periods, and recommended keeping the nature reserves in Israel out of bounds for honeybee colonies.

As any new species that integrates a natural community, the introduction of MIMS can potentially lead to modifications of the interactions among other cooccurring species, the structure of networks and ultimately the functioning of ecosystems (Tylianakis, 2008; Tylianakis et al., 2010, see also Fig. 1). While there are several studies focusing on invasive species and their impacts on plant and pollinator communities (e.g. Aizen et al., 2008; Stout and Morales, 2009; Traveset and Richardson, 2011, 2014, see the metaanalysis of Mollot et al., 2017), and on interaction networks (e.g. Aizen et al., 2008; Morales and Aizen, 2006; Stouffer et al., 2014; Traveset and Richardson, 2014), few studies have investigated the potential impacts of 


\section{BOX 3 Agrosystems}

Agrosystems are highly disturbed landscapes, characterized by a heterogeneous mosaic of habitats, strong spatial and temporal instability (Garder, 1996) and substantial reduction of the quality and quantity of seminatural areas (Benton et al., 2003; Duelli and Obrist, 2003; Tscharntke et al., 2005).

Agrosystems provide high concentrations of both plant and animal MIMS. Many MFC need insect pollination (Klein et al., 2007; Williams, 1994). Even though non-bee insect pollinators play a significant role in crop production, they are less efficient that bees per flower visit (Rader et al., 2009, 2015). Managed honeybees are the most economically valuable pollinators for monofloral crops and some seed, fruit and nut crops worldwide (Klein et al., 2007; Morse and Calderone, 2000), but other managed bee species are widely used owing to their more specific pollination service, such as bumblebees for tomatoes (Graystock et al., 2016; Van Engelsdorp and Meixner, 2010; Velthuis and Van Doorn, 2006). However, wild native species are highly efficient pollinators, especially the most common and abundant species (Kleijn et al., 2015; Rader et al., 2009) and complementarity between managed and wild native bee species can increase quality of MFC pollination (Garibaldi et al., 2013, 2016).

In intensive agricultural habitats, feeding resources for pollinators are mainly provided by wild flowering plants in seminatural remnants (e.g. grasslands, field margins, hedgerows; Ricketts et al., 2008; Rollin et al., 2013; Steffan-Dewenter and Tscharntke, 2001) and MFC for a short duration (Herrmann et al., 2007; Westphal et al., 2009). While native wild bees are mostly observed in seminatural habitats (Rollin et al., 2013, 2015), managed honeybees have strong preferences for MFC and tend to use seminatural areas less intensively when alternative floral resources increase in the landscape (Henry et al., 2012; Rollin et al., 2013). However, when MFC are not available, honeybees switch to natural areas with a significant increase of their abundance in these habitats (Rollin and Decourtye, 2015). During this period of food scarcity, wild bee communities show a significant decrease of their local scale diversity as compared to MFC flowering periods, while their local abundance and landscape-scale species diversity are the highest (Rollin and Decourtye, 2015; Rollin et al., 2015). These results provide indirect evidence that honeybees outcompete native bees in agrosystems during periods of food scarcity, with a spatial reorganization of wild bee species at the local scale in seminatural remnants.

In intensive agricultural landscapes, farming practices more friendly to bees are needed to alleviate potential competition for floral resources between wild and managed bee species. For example, intercropping practices with plant mixtures of interest for honeybees and beekeepers are being developed, even if their implementation still generates various agronomic constraints (Biniaś et al., 2015; Labreuche and Tosser, 2014). 


\section{BOX 4 Emergent MIMS-Sown Flower Strips}

The intensification of agriculture has caused dramatic declines in farmland biodiversity (Carvalheiro et al., 2013; Senapathi et al., 2015). Since the 1990s, agricultural policies have been developed in Europe to mitigate this loss through agrienvironmental schemes (AES). One AES is "sown wildflower strips", the aim of which is to create new ecological infrastructures by sowing attractive wild flowers on arable land (a few \% of the cultivated area). These ecological infrastructures fall within our definition of MIMS since they represent a massive introduction of managed species in the landscape.

Wildflower strips usually include mixtures of annual and biennial flowering species known to offer pollen and nectar rewards. Their aim is to promote pollination services, biological pest control, plant diversity and to support farmland bird populations by providing seeds as food resources and invertebrates as preys (Dicks et al., 2014).

Evaluations of the effects of wildflower strips in situ have yielded mixed results with only marginal to moderately positive effects of these AES on biodiversity (e.g. Albrecht et al., 2007; Dicks et al., 2014; Kleijn et al., 2006). Most studies acknowledged that common insects are the main beneficiaries of wildflower strips, which were not designed to have positive impacts on threatened or specialized species (Potts et al., 2006). Haaland et al. (2011) showed that sown wildflower strips support higher insect abundances and diversity than cropped habitats or other field margin management types such as sown grass margins and natural regeneration. These effects are perceptible at the plot scale but also in the wider landscape (Jönsson et al., 2015).

Although these results are encouraging, they also highlight the challenges ahead for the restoration of plant-pollinator interactions. Agro-ecological management practices must take into account common, but also rare species that require more conservation efforts. This "community approach" to pollinator conservation needs a stronger focus on the botanical composition of sown wildflower strips which should be tailored to the identity of pollinators and their ecological requirements (Blaauw and Isaacs, 2014; Blackmore and Goulson, 2014; Garratt et al., 2014; Tschumi et al., 2016) without systematically overlooking the need to conserve all species of pollinators (Kleijn et al., 2015).

MIMS (see Gill et al., 2016). The term MIMS refers both to alien species (Bombus terrestris later) and to geographically native ones (Brassica napus see later). Thus, whether native or alien, MIMS are plants or animals voluntarily introduced in high quantities for the sake of human needs. This might partly explain the lack of consideration of their potential effects on ecosystems. For 


\section{BOX 5 Buzz in the City}

Cities are scheduled to increase by more than $250 \%$ in the next 15 years, with urbanization being one of the main drivers of habitat fragmentation and associated biodiversity losses (Concepcion et al., 2015; Geslin et al., 2016a; Nieto et al., 2014). Many towns are taking into account the importance of biodiversity and try to set up conservation measures. However, regarding pollinators, the public policies and awareness campaigns are mainly focused on the introductions of numerous colonies of $A$. mellifera. Urban inhabitants associate pollination and A. mellifera colonies to the quality of their living environment, with beekeeping becoming increasingly popular in cities (Geslin et al., 2013). Honeybees have thus become a symbol of biodiversity for the general public, which reinforces the growth of urban apiculture. For example, in Paris (an area of $\sim 105 \mathrm{~km}^{2}$ ), more than 700 hives have been introduced in the last years (http://www.paris.fr/ actualites/paris-se-mobilise-pour-les-abeilles-3488).

An important diversity of wild bees might persist in cities and competition and/or spillover might occur between these species and Apis mellifera. Indeed, urban habitats support a relatively high biodiversity of wild bees (Poznan, 104 spp., Banaszak-Cibicka and Żmihorski, 2012; 291 spp. in the large urban area of Lyon Fortel et al., 2014; Paris, 44 spp., Geslin et al., 2016b; Brussels >100 spp., N. Vereecken et al., unpublished data). Therefore, caution should be taken when introducing high densities of $A$. mellifera in cities. Torné-Noguera et al. (2015) showed a negative impact on wild bee abundance when A. mellifera reached a density of 3.5 colonies $/ \mathrm{km}^{2}$ in a natural park in Spain. The city of Paris already harbours twice this density of beehives $\left(\sim 7\right.$ colonies $\left./ \mathrm{km}^{2}\right)$ and the city of London even more ( $\sim 10$ colonies $/ \mathrm{km}^{2}$; Alton and Ratnieks, 2016).

We argue here that MIMS in cities might be a counter-productive conservation measure for urban biodiversity, creating new pressures for wild species instead of preserving them. Other conservation practices might be developed in cities towards plant and pollinators such as sowing flowering communities and ecological gardening (Blackmore and Goulson, 2014), reduced use of pesticides (Muratet and Fontaine, 2015) or installing nesting habitats for pollinating insects (Fortel et al., 2016). We do not seek to oppose Apis and non-Apis conservation strategies (Aebi et al., 2012), but a priority is to determine the optimal densities of domesticated and wild pollinators to preserve both biodiversity and beekeeping activities. Additional work on this topic is strongly and urgently needed. 


\section{BOX 6 Emergent MIMS-Megachile}

The most intensively managed wild bee is certainly the Leafcutting bee Megachile rotundata (Pitts-Singer and Cane, 2011). Mostly used in North America (Canada, USA) for the pollination of alfalfa, whose production increases by $50 \%$ as a result of $M$. rotundata pollination, this solitary bee species has gregarious nesting habits facilitating its commercialization. $M$. rotundata fits in the definition of a MIMS, with an easy and cheap production allowing mass commercialization (the density of individuals may reach 150,000 bees/ha during alfalfa flowering, Pitts-Singer and Bosch, 2010; Pitts-Singer and Cane, 2011). M. rotundata has nesting requirements similar to those of many wild species in the United States, which could foster a competition for nesting sites (Barthell et al., 1998, see also Pitts-Singer and Cane, 2011). However, in the study of Barthell et al. (1998), M. rotundata only occupied a small percentage (3-4\%) of monitored artificial nests. Donovan (1980) argued that the competition for nesting resources between $M$. rotundata and native Hylaeinae might be very unlikely as nesting holes could not be a limiting factor.

To date, about 20 species of social and solitary bees are commercially reared for pollination services (Stout and Morales, 2009). To a lesser degree Osmia species are used to pollinate fruit crops such as pears and apples, including Osmia cornuta (Maccagnani et al., 2007), Osmia cornifrons (Matsumoto et al., 2009) and Osmia lignaria (Sheffield, 2014). The magnitude of introductions in the orchards varies from a few hundred individuals (Sheffield, 2014) to a few thousands (four boxes of 600 individuals in two pear orchards in Maccagnani et al., 2007).

Finally, many alternatives to classic commercialized pollinators have been developed in the last 20 years and the development of new commercial pollinator species is increasingly promoted by local managers. This is the case for stingless bees such as Trigona and Melipona species, which are increasingly used for greenhouse pollination (reviewed in Slaa et al., 2006).

instance, MFC have positive economic impacts and managed bees are positively perceived thanks to their role in the production of honey and in the pollination of plants (Goulson, 2003). Yet, both insect and plant MIMS can interact with other wild species, rearrange pollination networks at the landscape scale (Spiesman and Gratton, 2016), and either facilitate or impair interactions with coflowering wild plant communities (Holzschuh et al., 2011; Rollin et al., 2015).

Here we review the literature to analyse how MIMS can integrate plantpollinator systems. First, we introduce the main plant and animal MIMS 


\section{Without hives}

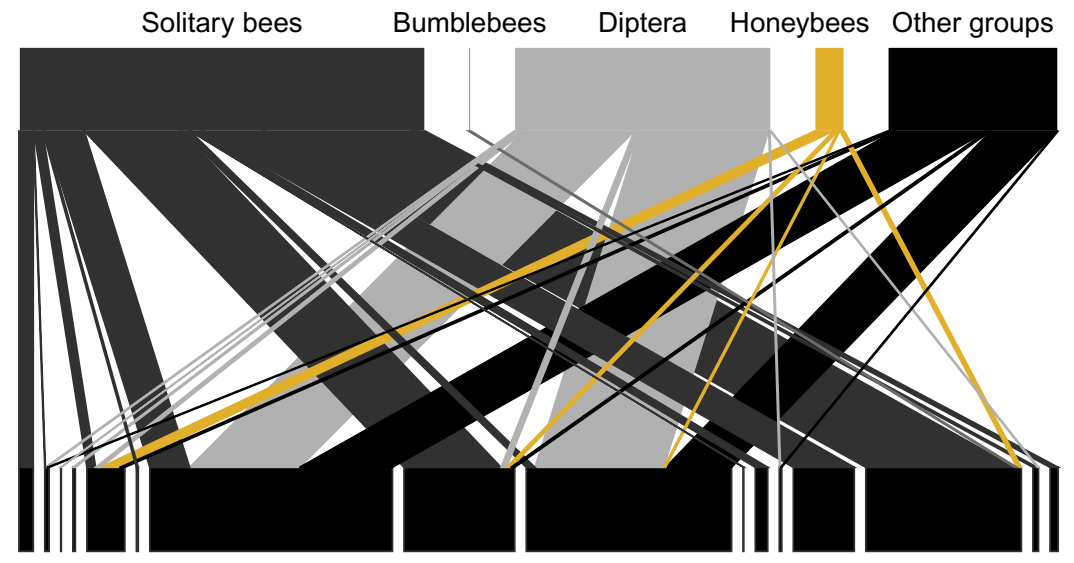

With hives

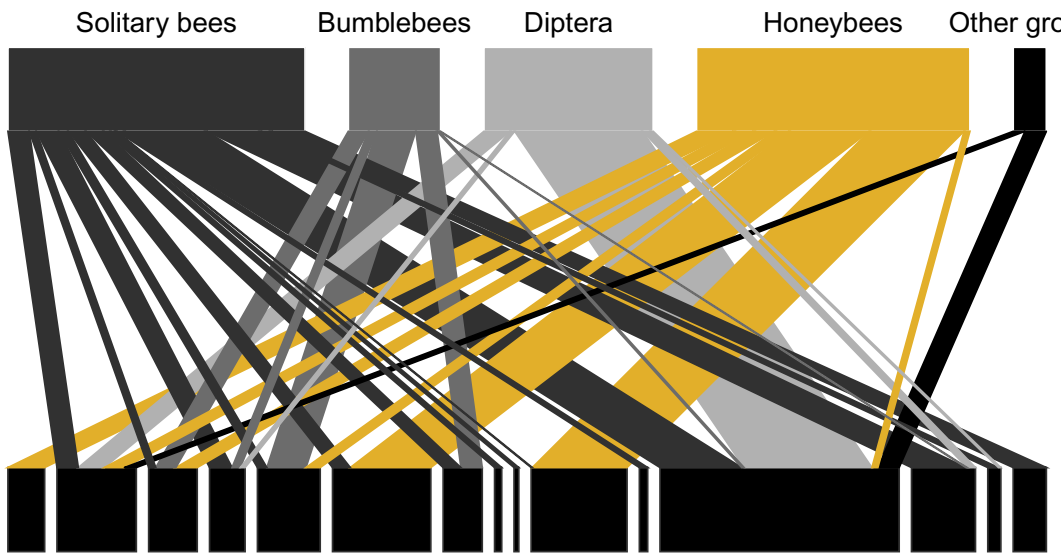

Fig. 1 Modifications of a plant-pollinator network after the introduction of five Apis mellifera colonies in an experimental site in Paris. Top squares represent flower-visitor morphogroups and bottom squares represent flowering plant species. The link widths represent the number of observed interactions between visitors and flowering plants. Data retrieved from $L$. Ropars et al. (unpublished data).

involved in pollination processes and we review the mechanisms by which they interact with other species. We analyse their role as either direct and indirect competitors, or facilitators in plant-pollinators communities (Fig. 2). In a second part, we analyse a published dataset of plant-pollinator networks (Fontaine and Thébault, 2015; Thébault and Fontaine, 2010) to 


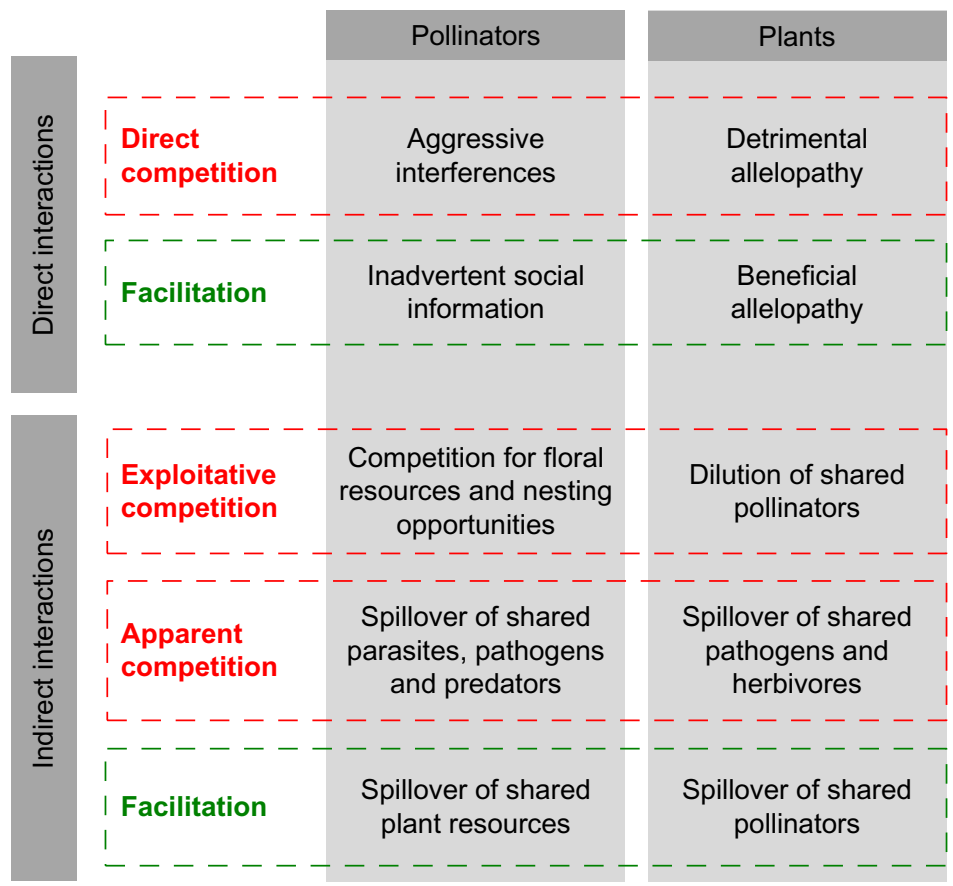

Fig. 2 Synthesis of possible ecological interactions between MIMS and wild pollinators or plants (see text for definitions). The introduction of managed plant or pollinator species may interfere with native interaction networks following a variety of ecological processes. Some of them are referred to as direct interactions because they occur with the simultaneous physical presence of both introduced and native organisms (e.g. aggressive interferences). Others are termed indirect interactions because they are indirectly mediated by a third party such as resources in exploitative competition or pathogens and predators in spillover events. MIMS may exert either detrimental (competitive) or beneficial (facilitative) effects on native interaction networks. Facilitation typically occurs when the focus native network already expressed any deficiency at the time of managed species introduction.

understand the position of MIMS in mutualistic networks and their impacts on network structure in terms of nestedness, connectance and modularity; and to infer their potential consequences on community functioning. We further present in detail several case studies on the introduction of MIMS in sensitive environments [islands (Box 1), natural and protected areas (Box 2), seminatural areas in agrosystems (Box 3)]. Finally, we also discuss the avenues of future research on new management practices and environmental policies such as sown flower strips (Box 4) and urban beekeeping (Box 5) as well as emergent MIMS (Box 6), and how those practices may lead to the spread of MIMS. 


\section{FIRST PART: IMPACTS OF MIMS IN PLANT} AND POLLINATOR COMMUNITIES

\subsection{The Case of Pollinators}

\subsubsection{Pollinating MIMS}

\subsubsection{Introduction}

The use of managed pollinators to pollinate crops has become more and more common with the increased dependency of agriculture crop production on animal pollination (Aizen et al., 2008; Lautenbach et al., 2012). Further, numerous managed honeybee colonies are brought into agricultural landscapes for honey production (Graystock et al., 2016; Morse, 1991). This translates into important fluxes of pollinators into agricultural and adjacent seminatural habitats during the flowering season of crops (Box 3). Globally, these managed pollinator species represent around 20 species among all social and solitary bee species (Stout and Morales, 2009). Three of these species, A. mellifera, B. terrestris and Megachile rotundata, have particularly extended their geographic range either due to voluntary or accidental introduction (Goulson, 2003; Box 6).

\subsubsection{The Honeybee, A. mellifera}

A. mellifera is used for honey production and to pollinate MFC such as almonds (Cunningham et al., 2016), mango (Geslin et al., 2016c), apples (Ramírez and Davenport, 2013), pears (Stern et al., 2004) and many others (Garibaldi et al., 2013, 2016).

Contrary to other Apis species that are restricted to Asia, ${ }^{\text {a }}$ the native geographical range of $A$. mellifera spans from Scandinavia to Central Asia and the African continent (Ruttner, 1988; Seeley, 1985; Sheppard and Meixner, 2003). However, its current geographical distribution encompasses almost all habitats on the planet, at the exception of deserts and areas of permafrost. Such a wide distribution is largely due to deliberate human introduction (Crane, 1975, 1999) by settlers on every newly colonized continent, combined with the fact that honeybees are highly polylectic (pollen generalist) with a very wide ecological (here, dietary) niche. Evidence from behavioural and palynological studies reveal that although workers may regularly specialize on the collection of pollen from a single locally abundant host plant, at

\footnotetext{
a Note that A. florea has recently expanded its geographic range in Jordan (Haddad et al., 2009) and is
} now spreading in Sudan (Lord and Nagi, 1987) and Ethiopia (Pauly and Hora, 2013). 
the colony level, they collect pollen from a very wide taxonomical range of flowering plants (e.g. Requier et al., 2015).

\subsubsection{The Large Earth Bumblebee, B. terrestris}

$B$. terrestris is currently the most widespread managed bumblebee species for pollination services. Since the 19th century, colonies of $B$. terrestris have been introduced in many parts of the world for commercial purpose (Graystock et al., 2016; Lye et al., 2011). It has originally a West Palearctic distribution, but populations are now present from the tip of the Argentinean Patagonia (Geslin and Morales, 2015) to the North of the Arctic Circle (Martinet et al., 2015). This bumblebee species also owes its success to its foraging skills. As summarized in Dafni and Shmida (1996), B. terrestris is a generalist pollinator, capable of foraging at low temperatures (Stelzer and Chittka, 2010), visiting deep corollas, presenting a variety of foraging behaviours (buzz pollination; nectar robbing), and is relatively easy to breed and to produce commercially (Velthuis and Van Doorn, 2006). B. terrestris does not produce honey, so it is used solely for pollination service in greenhouses, orchards (e.g. apples, pears, raspberry and avocado) or other highly valuable crops (e.g. peppers) to replace or supplement honeybee populations (Dafni et al., 2010; Goulson, 2003; Goulson and Hughes, 2015).

Today, the mass commercialization of $B$. terrestris colonies reaches more than two millions of traded colonies per year, representing an economic value of $€ 55$ million (Graystock et al., 2016; Velthuis and Van Doorn, 2006). Following this massive global trade of B. terrestris colonies, many countries reported cases of invasions (mostly due to queens escaped from greenhouses) such as in New Zealand, Israel, Japan, South Korea, China, Chile and Argentina (see Acosta et al., 2016 for a review). Today, $B$. terrestris is considered as one of the most globally invasive bee species, and, given the forecasts provided by species distribution modelling, the invasion is likely to amplify (Acosta et al., 2016).

In addition to $B$. terrestris, four other bumblebee species are reared worldwide and commercially distributed in high quantities for pollination service: B. lucorum, B. occidentalis, B. ignitus and B. impatiens (Velthuis and Van Doorn, 2006). The production is, however, substantially lower than for B. terrestris, with 55000 colonies produced per year for B. impatiens, the second most commonly reared species. Despite warnings regarding its use outdoor in nonnative areas, $B$. impatiens is used for pollination services as an alternative to $A$. mellifera (Artz and Nault, 2011) either in open fields or 
in greenhouse like in Mexico (Velthuis and Van Doorn, 2006). More recently, other bumblebee species have been used for pollination service, with a special interest in favouring local species including $B$. patagiatus in China (Zhang et al., 2015) or B. hypocrita in Japan (Williams et al., 2012).

\subsubsection{Direct Interactions Between MIMS and Wild Pollinators}

\subsubsection{Interference Competition}

There is little evidence of interference competition through aggressive behaviour between pollinating MIMS and wild pollinators. In Mexico, Cairns et al. (2005) observed competitive behaviour between A. mellifera and stingless bees, including aggressive contacts between species. There are descriptions of pollen theft by $A$. mellifera workers directly from bodies of native bees (Bombus and Megachile species), but these are considered as rare events (Jean, 2005; see also on Bombus, Brian, 1957; Inouye, 1978). Studies on commercial hives in New Zealand have shown that workers of A. mellifera could reduce wasp densities through aggressive interaction in forests where both bees and wasps foraged on honeydew exudates of the scale insect Ultracoelostoma brittini (Hempitera: Margarodidae) (Markwell et al., 1993).

Conversely, Frankie et al. (2005) did not observe any aggressive behaviour between Apis and non-Apis during a 5-year survey of bee visitation within gardens in a city of California (USA). Roubik (1978) reported on exploitative competition between honeybees and wild stingless bees, but no aggressive behaviour between bees for resources of either natural or artificial flowers. Studies on other MIMS such as the invasive B. terrestris on the island of Tasmania did not provide evidence of aggressive behaviour towards the local wild bee fauna (Hingston and McQuillan, 1999).

Overall, these studies show that aggressive interactions between MIMS pollinators on the one hand, and other unmanaged wild bees or wasps on the other hand are relatively seldom reported in the scientific literature. This suggests that interference competition with MIMS pollinators is unlikely to have significant consequences on unmanaged pollinating species.

\subsubsection{Facilitation Through Inadvertent Social Information}

Interactions between pollinator MIMS and wild pollinators can also involve social information (Danchin et al., 2004). Insect pollinators have been shown to use social information to optimize their foraging, either to locate rewarding patches (Baude et al., 2011) or to avoid predation (Dawson and 
Chittka, 2014). Although mainly studied at intra-specific level, information flow among pollinators also occurs between species (Dawson and Chittka, 2014; Goodale and Nieh, 2012). For example, Goodale and Nieh (2012) showed that $B$. impatiens was able to interpret $A$. mellifera alarm signals (presence of $A$. mellifera haemolymph) as an indication of a predation event. It remains to be investigated if massively introduced pollinators pheromones may modify wild pollinator behaviours (interactions with flower or predators avoidance).

\subsubsection{Indirect Interactions Between MIMS and Wild Pollinators}

As MIMS and wild pollinators are part of the same interaction network, the effects of one on the other can be indirect, i.e. mediated by shared partners, either plants leading to exploitative competition or parasites and pathogens leading to apparent competition.

\subsubsection{Exploitative Competition: Competition for Floral Resources}

As expressed by Stout and Morales (2009), exploitative competition for floral resources occurs when the consumption of limiting floral resources overlap between species, resulting in reduced population size, fecundity or survival for at least one of the interacting species.

We expect strong asymmetric competition for floral resources between the honeybee and wild bees for several reasons. First, there is a potential for strong numeric imbalance between wild and domestic bees. The number of workers within a single honeybee colony $(20,000-60,000)$ is more or less equivalent to, or even surpasses, the local density of all wild bees (a viable wild bee population reaches several tens to hundreds of individuals). Second, honeybee colonies are able to harvest large quantities of floral resources, either nectar or pollen, from various plant species. The annual amount of pollen collected by a single honeybee colony ranges from 20 to $50 \mathrm{~kg}$ (see Vereecken et al., 2015). Given that a honeybee visits up to 80 flowers per trip (representing 8-20 mg of pollen), we can estimate that 80-200 million of flowers will be visited for pollen by a single colony annually. Thus, Cane and Tepedino (2016) recently estimated that, during 3 months, a strong honeybee colony gathers as much pollen as could produce 100,000 progeny of $M$. rotundata. Third, honeybee colonies remain active throughout the year (except during cold months), while the vast majority of solitary wild bee species are only active for few weeks or months. Finally, contrary to wild bees, which are often described with 
small foraging flight distances (100-500 m, Greenleaf et al., 2007; Zurbuchen et al., 2010), honeybees can cover large areas for resources (mean distance: $1.5 \mathrm{~km}$; range from few metres to $10 \mathrm{~km}$; SteffanDewenter and Kuhn, 2003).

Goulson and Sparrow (2009) showed that the introduction of honeybees decreased the average body size of native bumblebees, a phenomenon observed when a sudden shortage of local food resources occurs, e.g. towards the end of the season. Other studies found that the maintenance of honeybee colonies had a significant impact on the fitness of bumblebees as measured by their colony weight, and the number and the weight of their reproducing caste (Elbgami et al., 2014; Thomson, 2004). Also detrimental effect of competition for resources between honeybee and bumblebee could be exacerbated by unfavourable climatic conditions (Thomson, 2016) or reduce resources availability in homogeneous landscapes (Herbertsson et al., 2016).

The introduction of honeybee colonies can also decrease the visitation frequency of wild bees on plants, as reported by studies on Mediterranean plants (Shavit et al., 2009), in the Japanese archipelago of Okasawara (Kato et al., 1999), in Australia (Paini and Roberts, 2005) and in Mexico (Badano and Vergara, 2011). Wild bees competing for floral resources with honeybees might also shift towards alternative plants that are sometimes taxonomically and chemically distant from their preferred plants (Roubi and Villanueva-Guttiérez, 2009; Schaffer et al., 1983; Thorp, 1996; WaltherHellwig et al., 2006). While this shift in visited plants might not hinder the local maintenance of polylectic species, which can exploit alternative food sources, it might represent a major obstacle for oligolectic species. Indeed, a shift towards plants belonging to different genera or families is strictly impossible for the latter, since they are physiologically and behaviourally adapted to a narrow spectrum of plants, which makes them overall more vulnerable (Biesmeijer et al., 2006) and prone to extinction (Nieto et al., 2014) in a context of land-use change affecting their host plant(s) (Biesmeijer et al., 2006; Carvalheiro et al., 2013).

However, competition for floral resources with honeybees will likely depend on the density of honeybee colonies. Steffan-Dewenter and Tscharntke (2000) reported a lack of competitive interactions between introduced honeybees and wild bees on a grassland with a density of 3.1 colonies $/ \mathrm{km}^{2}$. To date, this density is one of the very few threshold values (with Torné-Noguera et al., 2015; 3.5 colonies $/ \mathrm{km}^{2}$; see Box 2) 
recommended to conservation managers in natural protected areas. Yet, this study might have significantly underestimated competition because it focused on a single season, whereas the deleterious effects of competition through the analysis of the reproductive success of species interacting together may be detected several years after honeybee introduction. Moreover, this study only focused on polylectic species that nest in newly installed artificial shelters (bee hotels) and the effect on the community of soil-nesting bees was not investigated.

Many studies have reported high levels of resource overlap between B. terrestris and the local insect fauna such as in Argentina (B. dahlbomii; Morales et al., 2013), Japan (B. ardens, B. hypocrita and B. diversus; Dohzono et al., 2008; Inari et al., 2005; Matsumura et al., 2004; Nishikawa and Shimamura, 2016) and Tasmania (Hingston and McQuillan, 1998, 1999; Hingston et al., 2002). However, the presence of resource overlap does not necessarily indicate competition and evidence of such competition is difficult to get in natural conditions (reduced population, fecundity or survival of one or both species; Goulson, 2003).

A field removal experiment of B. terrestris queens conducted in Japan showed a subsequent increase of the queen's populations of the two Bombus species that overlapped with B. terrestris in their diet breadth (Nagamitsu et al., 2009). In Tasmania, Hingston and McQuillan (1999) found a reduced visitation rate of local Megachile (Chalicodoma) species and argued that a displacement of local species might be due to resource depletion by $B$. terrestris.

On the contrary, Goulson et al. (2002) found that, although A. mellifera presence was negatively correlated to wild bee presence, there was no correlation between the presence of $B$. terrestris and the abundance and richness of native pollinators. Similarly, Nishikawa and Shimamura (2016) and Nagamitsu et al. (2007) did not detect negative competitive effects between $B$. terrestris and local bumblebee species despite apparent resource overlaps.

The challenge to draw clear conclusions lies mostly in the difficulty to acquire information on the population dynamics of wild bees. Studies are often focused on correlative measures regarding spatial presence/absence of wild bees and MIMS (Stout and Morales, 2009) without direct measurement of bee fitness. Taken together, few studies truly described competition for floral resources between MIMS and wild bee species, especially oligolectic ones, and because such competition might occur in highly invaded locations, this question calls for future research in the near future. 


\subsubsection{Exploitative Competition: Competition for Nesting Opportunities}

Although most studies on the competitive interactions between managed and wild bees have focused on floral resources, a few studies have also addressed the issue of the availability and partitioning of nesting sites between species.

Inoue et al. (2008) have suggested that competition for nesting sites is the main mechanism for the displacement of native bumblebees by $B$. terrestris. Likewise, Matsumura et al. (2004) have highlighted the similarity between B. terrestris and local bumblebee species nests. Morales et al. (2013) suggested a potential competition for nesting resources between $B$. terrestris and other bumblebee species. In the study by Inoue et al. (2008), most bumblebee nests (native and terrestris confounded) were constructed in abandoned rodent nests. Authors suggested that $B$. terrestris might outcompete and exclude other species by occupying available nests earlier in the year. However, the competition for floral or nesting resources is unlikely to explain the collapse of some bumblebee populations such as the sudden regression of the native $B$. dahlbomii after the introduction of $B$. terrestris in South America (Morales et al., 2013).

\subsubsection{Apparent Competition: Spillover of Shared Parasites and Pathogens}

MIMS and wild pollinators can also interact negatively through pathogen transmission from infected to sympatric healthy populations (pathogen spillover; Daszak et al., 2000). The recent review of Graystock et al. (2016) reveals that pathogen spillover between pollinating MIMS and wild pollinators might be a strong cause of wild bee decline worldwide (see also Fürst et al., 2014; Meeus et al., 2011).

To date, studies on pollinators' pathogens and viruses have focused on honeybees. Honeybees are infected by a diversity of pathogens, such as the Varroa mite, Nosema apis (Microsporidia), the deformed wing RNA virus (DWV), and Nosema ceranae. N. ceranae was until recently specifically associated to the Asian honeybee A. cerana, but it is now considered as one of the drivers behind the massive decline of honeybee in Spain and in other parts of Europe (Higes et al., 2006, 2010). Some studies have also shown that honeybee pathogens and viruses can infect other pollinator species. For example, the DWV has been reported in wild specimens of $B$. terrestris and B. pascuorum from Germany and the United Kingdom (Evison et al., 2012; Genersch et al., 2006), as well as in B. huntii in the United States (Li et al., 2011). Recent studies carried out in the United Kingdom have shown that DWV and N. ceranae infected simultaneously 
honeybees and six native Bombus species. These infections appeared intimately associated, suggesting pathogen spillover from the honeybee colonies to the wild bees.

Bumblebees, particularly $B$. terrestris, are infected by several other pathogens such as Apicystis bombi (protozoan), Crithidia bombi (protozoan), Nosema bombi (Microsporidia), Locustacarus buchneri (Acari) (Cameron et al., 2016; Colla et al., 2006; Graystock et al., 2014, 2015, 2016; Otterstater and Thompson, 2008; Stout and Morales, 2009). There is now clear evidence of a high prevalence of parasites in commercially reared bumblebees (Colla et al., 2006; Graystock et al., 2013a, 2015, 2016). Tests on $B$. terrestris colonies retrieved from commercial supply showed that $25 \%$ of colonies were infected with both Crithidia spp. and N. bombi (Murray et al., 2013) and 77\% of colonies were infested by at least one parasite (Graystock et al., 2013a). Parasite spillover between managed and wild bumblebees has been highlighted in Japan, Europe, United States and South America (Graystock et al., 2016). Indeed, wild bumblebees foraging close to greenhouses supplied with commercial bumblebees showed higher prevalence of parasite infection than bumblebees collected further away (Colla et al., 2006; Murray et al., 2013; Otterstater and Thompson, 2008). In Argentina, Arbetman et al. (2012) provided evidence for a link between invasion of $B$. terrestris and infection by $A$. bombi in $B$. ruderatus (alien) and B. dahlbomii (native). Parasite spillover consequences for wild pollinators could be huge and remain largely underestimated (Fürst et al., 2014), because infections can strongly reduce fitness, survival and even foraging behaviour in wild populations (Graystock et al., 2013b, 2016, Garibaldi et al., 2016; Meeus et al., 2011). In Patagonia, the spectacular regression of the endemic $B$. dahlbomii following $B$. terrestris invasion has been suspected to be caused by pathogen spillover (Morales et al., 2013; Schmid-Hempel et al., 2014). In the United States, Cameron et al. (2011) observed a correlation between $N$. bombi infections and declining populations of eight native bumblebee species. The impact of individual drivers has received considerable interest from contemporary researchers, but the idea of synergistic effects between individual drivers - a more realistic approach to the drivers of decline-is increasingly discussed and investigated (Tylianakis et al., 2008). This represents a particularly promising avenue for future research not only on honeybees but also on non-Apis species, since several of the prominent pathogens or antagonists have a worldwide distribution; interactions between multiple drivers therefore occur de facto under field conditions (see Chen and Siede, 2007). 


\subsubsection{Apparent Competition: Spillover of Shared Predators}

Apparent competition between MIMS and wild pollinators might also occur through shared predators. The Asian Hornet Vespa velutina nigrithorax is an invasive species in Europe that mainly preys upon $A$. mellifera individuals (Villemant et al., 2006, 2011a). Analyses of prey residuals revealed that $V$. velutina can also prey upon wild Hymenoptera (Villemant et al., 2011b), and particularly on wild bees from the Halictidae family (Perrard et al., 2009). Thus, we might expect apparent competition between $A$. mellifera and wild bees mediated by $V$. velutina predation, but to date, no study has focused on the impact of $V$. velutina on wild pollinator populations.

\subsubsection{Facilitation: Spillover of Shared Plant Resources}

To our knowledge, there is no published evidence of facilitative effects between pollinating MIMS and wild pollinators. Such facilitative effects have been reported among coflowering plants to attract shared pollinators (e.g. Rathcke, 1983, see later). This could theoretically occur among pollinators, if a plant species is pollinated sequentially by a pollinating MIMS and a wild pollinator, leading to increased plant reproduction. Facilitative effects might also arise from asymmetry in plant-pollinator interactions: if a MIMS pollinator efficiently pollinates plant species upon which wild pollinators are dependent (Bascompte et al., 2006; Vázquez and Aizen, 2004). However, both $A$. mellifera and $B$. terrestris have long periods of foraging activity and these facilitative effects might be buffered by within season competition for resources with wild pollinators.

\subsection{The Case of Plants}

Here we review the impacts of plant MIMS on nearby natural plant communities, by examining their direct or indirect interactions through shared species (pollinators and herbivores/pathogens), and how these effects translate into the reproductive success and stability of wild plant communities. We focus on cultivated species of intensive farmland habitats, especially MFC such as oilseed rape (B. napus), sunflower (Helianthus annuus), field bean (Vicia faba), phacelia (Phacelia tanacetifolia), wild mustard (Sinapis arvensis), potato (Solanum tuberosum) and clover (Trifolium spp.). However, most of the following examples are extracted from studies based on oilseed rape fields, for which land cover has increased by 49.9\% between 2000 and 2010 in Europe (European Commission, 2011), largely due to an increased demand for biofuel. 
Given the increase in pollinator densities commonly ascribed to MFC, from the local to the landscape scale (Holzschuh et al., 2013; Jauker et al., 2012; Knight et al., 2009; Westphal et al., 2003, 2009; Box 3), it seems likely that competition or facilitation between coflowering plants via shared pollinators would be influenced by MFC. For example, in oilseed rape (MFC), a single field provides 350,000-700,000 plants per hectare, each producing more than 100 flowers (Hoyle et al., 2007) during a flowering period of about 4 weeks. This huge, temporary peak of resources available to pollinators can entirely rearrange pollination networks at the landscape scale (Spiesman and Gratton, 2016), and either facilitate or impair pollination networks with coflowering wild plant communities (Rollin et al., 2015).Thus, it may indirectly influence a coflowering plant reproduction via the modification of shared pollinators foraging activity (Carvalheiro et al., 2014).

\subsubsection{Direct Interaction Between MIMS and Natural Plant Communities: Allelopathy}

Direct interactions between crops and native plant communities can occur through competition for space or light and are thus not specific of MFC. On the contrary, allelopathy, which has been defined as "direct or indirect harmful (or beneficial) effects of one plant on another through the production of chemical compounds that escape into the environment" (Rice, 1984) has been reported for several MFC. Many allelochemicals from plant tissues, usually secondary plant products, can cause germination or growth inhibition of the target wild species. Most research on allelopathy has focused on the effect of interactions among weeds (Newman and Rovira, 1975), among crops (Hegde and Miller, 1990), but also among weeds and crops (Rice, 1984; Turk and Tawaha, 2003). Researchers have evaluated the allelopathic potential of crops for weed control in order to discover novel natural plant compounds with herbicidal properties (Massantini et al., 1977; Maun, 1977; Rawat et al., 2012). There are several examples of allelopathy from MFC to weeds. Brassica species have been frequently cited as allelopathic crops (Bell and Muller, 1973). For example, Turk and Tawaha (2003) experimentally demonstrated that a plant extract from Brassica nigra inhibited the germination, seedling length and weight of Avena fatua. There are also examples of allelopathic effects of other crops such as white Lupin (Lupinus albus), sweetcorn (Zea mays) and sunflower (H. annus) on the surrounding vegetation. Rawat et al. (2012) demonstrated the allelopatic effect of sunflower on a weed species (Trianthema portulacastrum) and Leather (1983) reported that 
dried sunflower leaf and stem tissues inhibited broadleaf weed seedling growth but had little effect on grass weeds. Even if it is difficult to disentangle allelopathy from other mutual plant interference effects such as competition for light, whether or not plant MIMS can influence the composition of natural plant communities within field boundaries through allelopathy remains to be investigated. In addition to the effects on seed germination or the development of vegetative parts in the targeted plants, plant competition also affects floral traits (corolla size, nectar content), i.e. the primary advertisement cues in plant-pollinator interactions (Baude et al., 2011; Flacher et al., 2015).

\subsubsection{Indirect Interactions Between MIMS and Wild Plants}

\subsubsection{Facilitation: Spillover of Shared Pollinators}

Facilitation of pollination takes place when the presence of a plant species increases the rate of pollinator visitation and reproductive success of a second species sharing pollinators. While facilitation through spillover of pollinators from natural habitats to agricultural ones has been well documented, there are fewer studies addressing the effects of pollinators from managed habitats on natural ones (Blitzer et al., 2012). Spillover from managed to natural habitats occurs if pollinators benefit from the high productivity of managed habitats and then move to natural habitats, which are assumed to be less productive in floral rewards for pollinators (pollen and nectar). In addition to Westphal et al. (2003), who reported that increased bumblebee densities in MFC resulted in higher visitation rates in P. tanacetifolia, other studies using phytometers ${ }^{\mathrm{b}}$ found that MFC facilitated a pollinator spillover. Cussans et al. (2010) found that fruit set of Lotus corniculatus increased when planted close to oilseed rape and Hanley et al. (2011) observed higher effectiveness of bumblebees visiting flower margins adjacent to MFC during the flowering period. However, the positive effect of MFC on native communities appears to be limited to a restricted number of insect species (Le Féon et al., 2010; Rollin et al., 2013, 2015) and to be limited in time (Hanley et al., 2011; Westphal et al., 2009). Contrary to studies on alien plant species, the underlying mechanisms of facilitation are rarely investigated. For example, in Osmia bicornis ( = O. rufa), a wild mason bee species active at the time of the MFC flowering season, larger amounts of oilseed rape led to increased

\footnotetext{
$\overline{\mathrm{b}}$ A phytometer being a plant or group of plants grown usually under controlled conditions and used as a measure of the responses to various environmental factors. Following Albrecht et al. (2007), phytometers are obligatory outcrossing plant species relying on insect for pollination and commonly used to estimate pollination success.
} 
nest building and number of produced offspring, but no evidence was available concerning the spillover of these beneficial aspects on the pollination of natural habitats (Jauker et al., 2012). Overall, this spillover may occur in conditions where agricultural habitats are subject to biodiversity-friendly management practices such as organic farming. Orford et al. (2016) have shown that experimentally enhancing plant species diversity of conventional agricultural grasslands was associated to increases in functional diversity, species richness and abundance of pollinators. This, in turn, led to increased pollination efficiency of a wild phytometer species, the red campion (Silene dioica). Also, Hardman et al. (2016) focused on the impact of wildlifefriendly farming practices on the pollination service delivered to a nonMIMS phytometer species (Eschscholtzia californica) and showed that organic farming practices supported higher densities of flowers and a better fruit set through increased diversity of floral resources in crop habitats.

\subsubsection{Exploitation Competition: Dilution of Shared Pollinators}

Competition for pollination occurs when the presence of a plant species induces pollen limitation, leading to a reduced reproductive success, in a second species sharing pollinators.

Negative effects of coflowering plant species on flower visitation and reproductive success of a focal species are known for plants within a local community (e.g. Bell et al., 2005), but less evidence is available for coflowering plant species interacting with plant MIMS.

Holzschuh et al. (2011) analysed whether abundance of oilseed rape leads to transient dilution of pollinators in the landscape and to increased competition for pollination between this crop MIMS and wild plant species. They showed that bumblebee abundance in grasslands decreased when the proportion of oilseed rape within a $1 \mathrm{~km}$ radius increased from $5 \%$ to $15 \%$, and this led to a $20 \%$ decrease in seed set of Primula veris, a coflowering wild plant species. However, proximate mechanisms for reduced reproductive success of native plant communities confronted to coflowering MIMS are rarely investigated. Following the examples of alien species literature, reduced reproductive success of native plant communities may be related to (i) reduced pollinator visitation to native plants in the presence of preferred cultivated plants, so that conspecific pollen deposition is diminished in native plants (Campbell and Motten, 1985), or (ii) switches of pollinators between cultivated and native flowers, which can lead to increased heterospecific pollen deposition and/or decreased conspecific pollen deposition (Morales and Traveset, 2009). This has been reported by Marrero et al. 
(2016) who recorded an increase in heterospecific pollen deposition on stigmas of native species in landscapes subjected to agricultural management. Also, Diekötter et al. (2010) investigated changes in frequency of plantpollinator interactions resulting from pollinator community shifts towards the species that would benefit from plant MIMS recurrent resource pulses. In a phytometer study with Trifolium pratense, these authors observed a change in bumblebee visitation behaviour and bumblebee communities composition associated with increased oilseed rape cultivation. Increasing amounts of oilseed rape in the landscape led to a decrease in long-tongued bumblebees visiting $T$. pratense plants that have deep corollas. The simultaneous increase of nectar robbing by short-tongued bees suggests that resource depletion is a likely explanation for the abundance decline of long-tongued bumblebees. However, this decline did not translate in an effect on seed set of $T$. pratense.

\subsubsection{Apparent Competition: Spillover of Shared Herbivores or Pathogens}

Apparent competition mediated by shared herbivores or pathogens is susceptible to occur between wild plants and plant MIMS (reviewed in Rand et al., 2006). Apparent facilitation between some MIMS and wild plants might also arise if they share predators/parasites of their herbivores or pathogens (Rand et al., 2006). Indirect effects mediated by antagonists (e.g. herbivores, pathogens) have been mainly investigated between wild and cultivated plants. Indeed, numerous studies have considered the spillover of herbivores, pathogens or natural enemies from natural to agricultural habitats and its consequences on crop yields (Blitzer et al., 2012; Power and Mitchell, 2004). Few studies have considered spillovers from agricultural areas to natural habitats, and the related indirect effects of plant MIMS on wild plants.

We expect strong apparent competition mediated by plant MIMS on wild plants due to differences in productivity between agricultural and natural habitats. Indeed, the high abundance of MIMS (see earlier) could maintain high abundance of herbivores, natural enemies and pathogens, and thus strongly affect native communities sharing these antagonist species. Several studies have emphasized the potential consequences of existing shared pathogens and viruses between crops and wild plants on native plant diversity and pathogen evolution (Burdon and Thrall, 2008; Jones and Coutts, 2015). A few studies have shown herbivore spillover and consequent apparent competition from crops to natural vegetation (Blitzer et al., 2012). McKone et al. (2001) found that adult corn-rootworm beetles (Diabrotica barberi), the larvae of which feed on corn, had higher densities in 
tall-grass prairie located close to fields and reduced the seed set of native species in these endangered tall-grass ecosystems. More recently, Squires et al. (2009) also showed the spillover of diamondback moth (Plutella xylostella) from agricultural Brassicaceae to wild native Brassicaceae species (Braya longii and Braya fernaldii), leading to a $60 \%$ decrease in seed set among damaged plants (about $50 \%$ of B. longii and B. fernaldii individuals). Chamberlain et al. (2013) also looked at the consequence of proximity to crop sunflower for abundance of antagonists of crop wild relatives. However, they found higher abundances of herbivores and seed predators far from the crop, which might be due to use of pesticides in crops leading to fewer enemies nearby crops or due to preference of antagonists for the crop (more attractive than the wild species). Indirect interactions between MIMS and wild plants might also vary temporally. Spillover could be related to temporal shifts in resources with active emigration of herbivores or predators once crops senesce or are harvested. Adler et al. (2014) studied the dispersion of two generalist crop herbivores (sweet potato whitefly, Bemisia tabaci and western flower thrips, Frankliniella occidentalis) to nearby desert habitat during the cropping season. They found whiteflies on 6 plant species and thrips on 19 out of 36 desert plant species and they further showed that the spillover of whitefly depended on the cropping stage (i.e. planting, growing, presanitation, sanitation stages). Last, spillover from crop MIMS may also affect trophic interactions on wild plant species of surrounding habitats, as shown by Gladbach et al. (2011) who investigated how oilseed rape affects the wild species $S$. arvensis through its pollen beetles (Meligethes aeneus) and their parasitoids (Tersilochus heterocerus). They found a spillover effect only for the parasitoids, but not for the pollen beetle, with parasitism rates benefiting from increasing presence of oilseed rape in the landscape.

\subsection{MIMS as Competitors or Facilitators-Consequences for Communities}

\subsubsection{Pollinators}

Pollinator MIMS impact on plant-pollinator interactions through both other pollinating species and the plant community with which they interact (Fig. 2). In Boxes 1-3, we developed the potential consequences of pollinating MIMS introductions in vulnerable ecosystems as well as in agrosystems. Traveset and Richardson (2006, 2011, 2014) and Dohzono and Yokoyama (2010) reviewed the consequences of the introduction of pollinating MIMS on plant communities and highlighted three main 
mechanisms which may disrupt mutualistic interactions: (i) a decrease in the quantity or quality of conspecific pollen received by wild plants due to insect diet preferences or cheating behaviour (nectar robbing), (ii) a reinforcement of invasive plant pollination through invasion meltdown ${ }^{c}$ and (iii) a lower reproductive success for plant species suffering of pollination deficit, especially in areas with scarce pollinators (Sanguinetti and Singer, 2014). Taken together, these mechanisms could have major collateral effects on native pollinators through modifications of plant resource availability.

To date, few studies have addressed the issue of the introduction of honeybee hives on the dynamics of native plant communities. It has been documented that introduced colonies enhance the visitation frequency of honeybees on invasive plant species, enhancing their reproduction (e.g. the effect on the purple loosestrife, Lythrum salicaria, in America: Barthell et al., 2001; Mal et al., 1992). By contrast, other studies have demonstrated that the introduction of honeybee hives can negatively affect the reproductive success of plants through increased pollen theft (Hargreaves et al., 2009), nectar robbing (Kenta et al., 2007), physical damage to the flowers (Dohzono et al., 2008) or through the disruptive influence of honeybee workers on the patterns of pollen transfer among compatible plants that have otherwise evolved highly specialized interactions with native pollinators (Gross and Mackay, 1998; Vaughton, 1996; Watts et al., 2012).

Other studies have shown that these effects are not restricted to honeybees. B. terrestris can also have collateral effects on the local floral communities and, in turn, on the wild bee species visiting with them. For example, Sanguinetti and Singer (2014) evidenced better reproductive success of a native orchid from Argentina due to more frequent visits by $B$. terrestris than by the native $B$. dahlbomii. However, deleterious effects for the local fauna following invasions of $B$. terrestris are frequently reported. In a cage experiment, Kenta et al. (2007) showed a decrease in reproductive success for five native plants following $B$. terrestris visits compared with native bumblebee visits. Also, B. terrestris showed a preference for exotic species in Argentina (Montalva et al., 2011) and promoted the invasion of a weed (Lupinus arboreus) in Tasmania through pollination (Stout et al., 2002). B. terrestris is able to rob flowers by perforating floral tubes which can damage flowers and reduce their reproductive success by repelling their native pollinators (Dohzono et al., 2008). Moreover, Sáez et al. (2014) showed that

Following Traveset and Richardson (2014) invasion meltdown are "community-level phenomenon whereby alien species enhance one another's establishment, spread and impacts”. 
$B$. terrestris can also alter the reproductive success and production of some MFC (Rubus idaeus) by damaging flowers and stigmas through overvisitation (see also Aizen et al., 2014).

\subsubsection{Plants}

The range of reported impacts of plant MIMS on natural plant communities vary from facilitation to competition, occurring directly or indirectly through shared pollinators and herbivores/pathogens (Fig. 2). The magnitude of the effect of plant MIMS on natural plant community and the outcome of the interaction are likely to be mediated by several parameters. First, phylogenetic constraints influencing the proximity in plant traits like flower morphology (for pollinators) or secondary metabolites (against herbivores) between the cultivated and wild plants probably matters, as closely related plants tend to share pollinators and herbivores (Carvalheiro et al., 2014; Fontaine and Thébault, 2015). Yet, most studies on the impacts of MFC on natural communities are based on oilseed rape (see Box 3 and Table S1 (http://dx.doi.org/10.1016/bs.aecr.2016.10.007)); and this limits our ability to generalize the results with other crops. Second, the spatial scale considered when studying the interactions between plant MIMS and natural plant communities is important. Holzschuh et al. (2013) suggest that smallscale effects of oilseed rape are much stronger than landscape-scale effects, at least for solitary bees, which perceive their environment at smaller scales than bumblebees (Westphal et al., 2006). Third, in view of the contrasting responses of pollinators to MFC during or after flowering, studies should also consider the temporal scales. Short-term effects (during vs after MFC flowering) as well as long-term effects via crop rotations that result in annual changes in the distribution of MFC fields might modify the interactions between plant MIMS and natural plant communities. For example, we may observe transient impact of MFC on pollinator populations and wild plant pollination during the flowering that does not necessarily remain after the flowering season (Hanley et al., 2011; Jauker et al., 2012). Furthermore, by influencing pollinator population dynamics, plant MIMS might induce competition for pollinators during mass flowering that potentially translate into facilitation at larger time scales. Fourth, the pollinating insect species involved in indirect interactions between MIMS and wild plants might differ in their phenology and resource requirements. Agricultural MIMS provide food for pollinators at a given moment in the season, but not later in the season, when reproduction of many pollinating species occurs (Requier et al., 2015; Westphal et al., 2009). Early season pollinating species are thus 
more likely to be favoured by nectar and pollen resource pulses from MFC. Increasing surfaces occupied by agricultural MIMS can also lead to a shortage of nesting sites for wild pollinators. For example, oilseed rape may increase competition among cavity-nesting bee species when nesting sites are the most limiting resource (Steffan-Dewenter and Schiele, 2008). Many solitary species depend on preexisting above-ground cavities or specific soil microhabitats often associated with seminatural habitats (Cane et al., 2007). These habitats have become increasingly scarce in modern agroecosystems (Potts et al., 2010), leading to pollination deficit in agricultural systems. Overall, agricultural MIMS may favour nonsocial, early reproducing pollinator species (Jauker et al., 2012), and ultimately early reproducing wild plant species, but be globally detrimental to diversity of wild plant communities. Thus, it is questionable whether the exclusive provision of food resources by transient MFC sustainably promotes pollinator reproduction in these systems. An increase in the amount of food resources in the landscape through plant MIMS is expected to benefit wild bees only if the amount of nesting habitats is simultaneously increasing. Last, both the enhancement of facilitation processes and the buffering of competitive interactions appear to depend on biodiversity-friendly management practices. The species diversity within a plant community can enhance pollination due to positive relations between plant and pollinator diversities (Ebeling et al., 2012). It also renders plantpollinator interaction networks more resilient to changes in floral resources (Tiedeken and Stout, 2015) that are prevalent in MIMS-dominated communities. Indeed, Kovács-Hostyánszki et al. (2013) underlined that resources provided by MFC are most beneficial for wild populations of bees and plants if seminatural habitats are available, providing continuous nesting and food resources during the season. In nonagricultural habitats, buffering the impacts of plant MIMS, be they ornamental or invasive, is also linked to the preservation of floral diversity (Blackmore and Goulson, 2014; Kaluza et al., 2016).

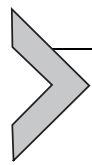

3. SECOND PART: MIMS IN PLANT-POLLINATOR NETWORKS

\subsection{Impacts of MIMS on the Structure of Plant-Pollinator Networks}

\subsubsection{The Case of Pollinators}

Few studies have investigated the impact of pollinator MIMS on plantpollinator network structure. During the past 5 years, two studies have, 
however, started to assess the consequences of $A$. mellifera on pollination networks. Santos et al. (2012) studied six plants-flower visitors networks in a region of Brazil where beekeeping is intensive and $A$. mellifera is feral and considered as an invasive species. All six networks had $A$. mellifera present and showed that removal of $A$. mellifera and associated links in these networks lead to decreasing nestedness and increasing modularity. However, network connectance was not affected by $A$. mellifera removal and authors did not find any correlation between network structure and the proportion of interactions made by $A$. mellifera in the networks. Giannini et al. (2015) studied 21 plant-bee weighted interaction networks from different ecosystem types, also in Brazil. They found that A. mellifera generalism and mean interaction strength was correlated to nestedness and plant niche overlap in their networks.

Being a hub responsible of a large proportion of connections, it can be expected that removal of $A$. mellifera would affect functional properties such as network robustness to extinctions (sensu Burgos et al., 2007). Surprisingly, Santos et al. (2012) found that robustness was unaffected by the removal of $A$. mellifera. However, authors reached this conclusion by considering simulated node deletion in networks in which $A$. mellifera was always present instead of comparing actually observed networks with and without A. mellifera. To assess the consequences of pollinator MIMS on plant-pollinator networks, other potential effects should be considered such as pollinator niche rewiring (Kaiser-Bunbury et al., 2010). Pollinators are able to switch to alternative plant species in response to changes in local species floral abundances (Tiedeken and Stout, 2015) or to changes in pollinator densities (Fontaine et al., 2008). To our knowledge, no study has yet compared plant-pollinator networks in the presence and absence of pollinator MIMS, and this clearly deserves future attention.

\subsubsection{The Case of Plants}

Very few studies have considered the consequences of MFC on pollinator communities and on the reproduction of some focal natural plant species from a network perspective. A few studies have considered the consequences of distance from natural habitats on within-crop plant-pollinator networks (Carvalheiro et al., 2010, 2012). These studies demonstrate that the diversity of pollinators on crops declines with increasing distance to natural habitats, both in mango plantations (Carvalheiro et al., 2010) and in sunflower fields (Carvalheiro et al., 2012, see also Ricketts et al., 2008). When distance to natural habitats increases, the decrease in pollinator diversity also 
leads to a reduction of network complexity up to the single couple MFCmanaged honeybees (see Box 3). In Carvalheiro et al. (2012), this reduction of pollinator diversity and network complexity is correlated with a reduction of crop production, mainly because managed honeybees move less between flowers at lower pollinator diversity. However, these two studies also show that interaction networks of crop fields are more complex and diverse during MIMS flowering period, probably due to the huge floral cover offered, although this effect is mostly present on the edges. Stanley and Stout (2014) suggested that field edges provide alternative resources to pollinators even during crop mass flowering. They found that oilseed rape and coflowering plant species shared pollinators, which is in agreement with the results of Carvalheiro et al. (2010, 2012).

To our knowledge, no study has precisely investigated the impact of MFC on the structure of plant-pollinator networks, focusing on network descriptors, and at a larger scale. Plant MIMS can be diverse, with different morphologies or phenologies (e.g. oilseed rape, sunflowers, peas). We might thus expect that their position in plant-pollination networks will be variable, depending on their floral traits and attractiveness. All MFC are present in high densities at some time of the year. This high abundance argues in favour of some characteristics of networks. We have evidence that species density or biomass is correlated with several structural properties like generalism (Sauve et al., 2016; Spiesman and Gratton, 2016) through pollinator rewiring capacities or higher encounter probabilities (Fort et al., 2016). A recent study suggests that oilseed rape is central in plant-pollinator networks in crop fields when it is flowering (Stanley, 2013). However, overall network structure is unaffected by mass flowering of oilseed rape in this case (i.e. network descriptors such as nestedness and connectance are similar during and after flowering), which suggests that network structure might be robust to such pulses of resources (Stanley, 2013).

\subsection{Case Studies of the Position of MIMS in Pollination Webs}

\subsubsection{A. mellifera in Plant-Pollinator Networks}

We analysed the position of $A$. mellifera in plant-pollinator networks from a database consisting of 63 community-wide qualitative pollination webs from 38 publications (Fontaine and Thébault, 2015; Thébault and Fontaine, 2010). We compared the position of A. mellifera in the network to that of other pollinators in terms of generalism or contribution to networks nestedness (how niche of specialized species are included in the ones of 
generalists) and modularity (how networks are divided in groups with few interactions between themselves). We chose to consider $A$. mellifera because it is the most widespread managed pollinator species and it occurs in many networks of the database. No information was available on whether A. mellifera populations were managed or not in the network studied. However, A. mellifera position in the networks can still give some important insights on the potential impact of this important MIMS on the structure of pollination networks. We calculated the degree (i.e. number of links), the contribution to nestedness and the topological role within modules of all pollinator species in the networks. The nestedness contribution of a species quantifies the degree to which observed network nestedness is modified when only the interactions of the focal species are randomized (Saavedra et al., 2011). Modularity defines the degree of compartmentalization of networks and species can be characterized according to their within-module degree $(z)$ and their among-module connectivity (c, Guimera and Amaral, 2005; Olesen et al., 2007). Species with high $z$ values are important for connecting species inside the same module and species with high $c$ values connect different modules.

A. mellifera was present in about $75 \%$ of the network datasets (47 webs out of 63). In those 47 networks, the proportion of interactions due to A. mellifera in the web (i.e. number of links of $A$. mellifera over the total number of links in the network) ranged between $0.23 \%$ and $23 \%$ (mean $=4.88$ and $\mathrm{sd}=4.48)$. A. mellifera was on average more generalist than other pollinators in the network (i.e. A. mellifera degree is in most cases in the 90th percentile, meaning that only $10 \%$ of the pollinator species in the network have the same or a higher degree; see Fig. 3B). A. mellifera also contributed more to nestedness than the average pollinator (Fig. 3C), and it had in most cases higher within-module degree (Fig. 3D) and higher among-module connectivity (Fig. 3E) than most pollinators in the network. These results thus support the idea that $A$. mellifera tends to be a highly generalist pollinator species that contributes to network nestedness and acts both as a connector within its own module as well as between modules (Giannini et al., 2015; Santos et al., 2012).

\subsubsection{MFC in Plant-Pollinator Networks}

We analysed the position of plant MIMS in two available datasets describing interactions between plants and flower visitors in farmlands (Fig. 4). Both 
A

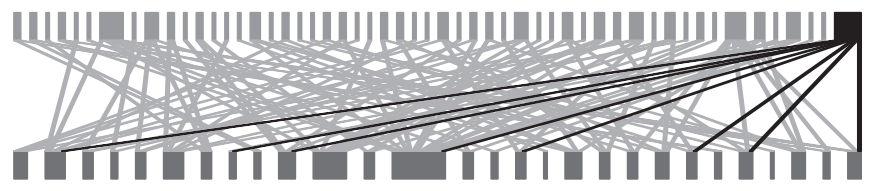

B

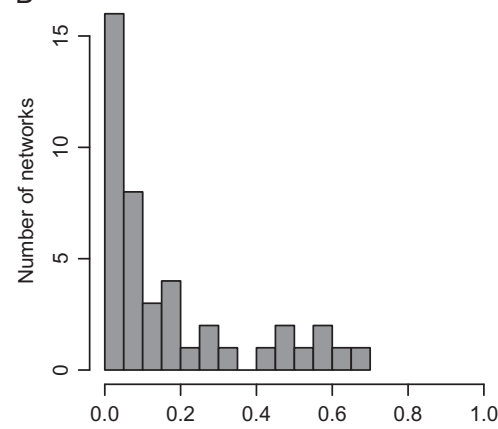

Proportion of species with higher degree than A. mellifera

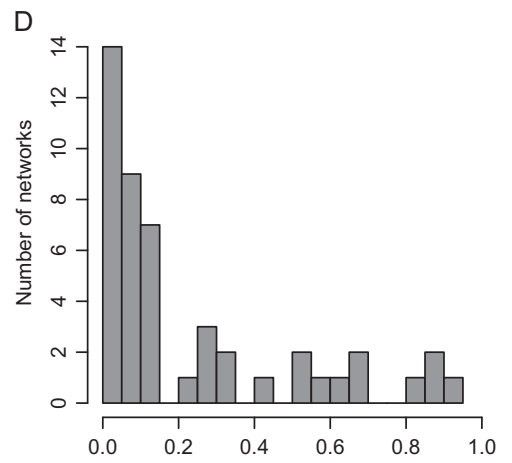

Proportion of species with higher within-module degree
C

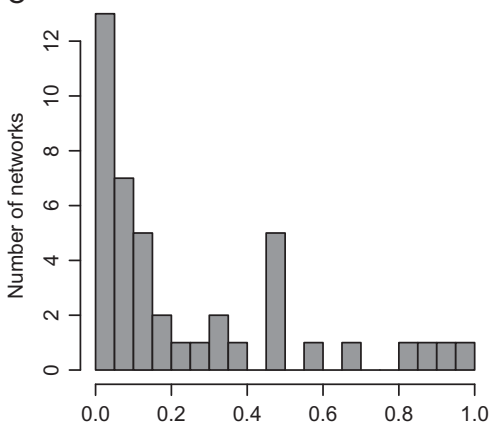

Proportion of species with higher nested contribution

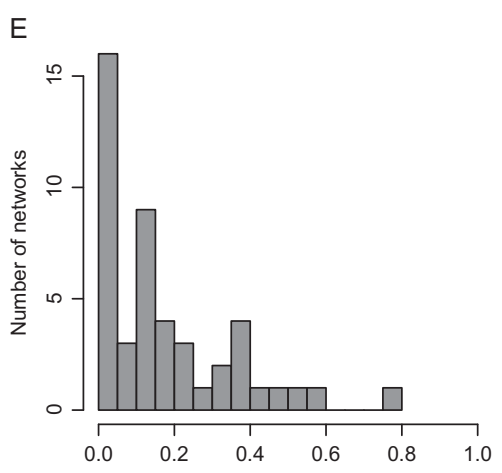

Proportion of species with higher among-module connectivity

Fig. 3 Example of plant-pollinator network with Apis mellifera taken from Ramirez and Brito (1992) (A) position of A. mellifera in plant-pollinator networks for degree (B), nestedness contribution (C) and modularity (D-E). In (A), rectangles at the bottom of the web correspond to plant (pollinator) species and the size of the rectangles is proportional to species degree. A. mellifera and its interactions are in black, while other pollinators are represented in grey. In (B and $C)$, the position of Apis mellifera in a given network is represented as the proportion of pollinators in the network with similar or higher degree $(B)$ and nestedness contribution $(C)$ than itself. In ( $D$ and $E$ ), the position of Apis mellifera in a given network is represented as the proportion of pollinators in the network with similar or higher within-module degree $z$ (D) and among-module connectivity $c(C)$ than itself. 
A

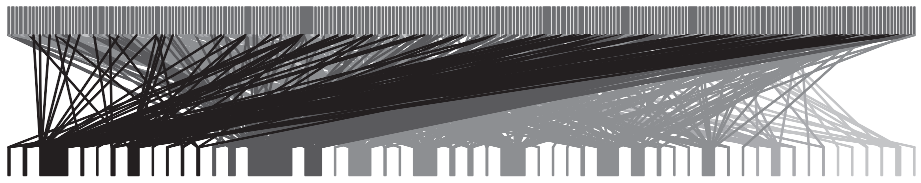

B

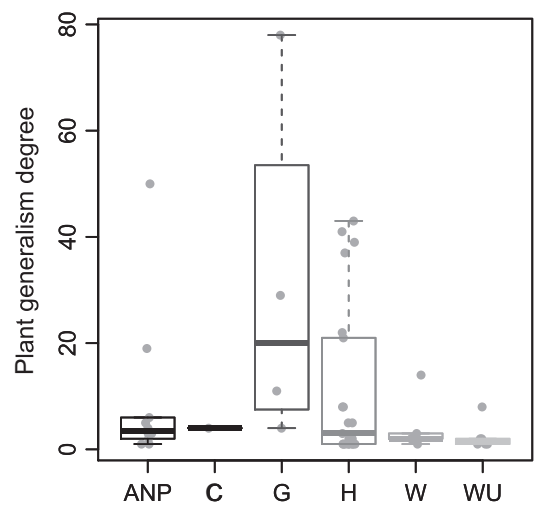

C

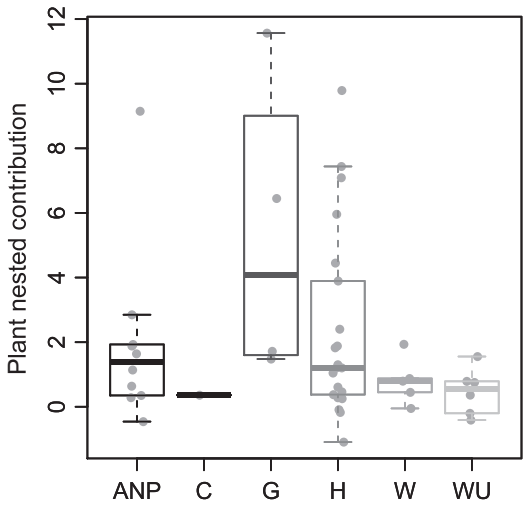

D

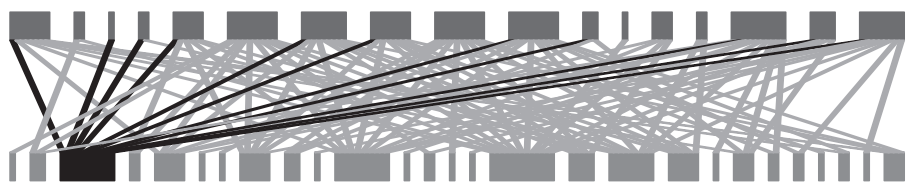

$\mathrm{E}$

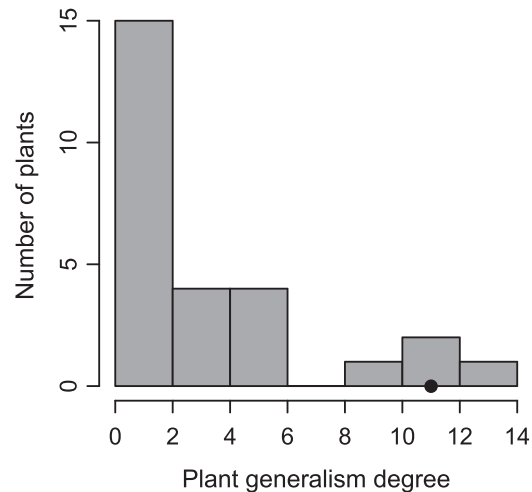

$\mathrm{F}$

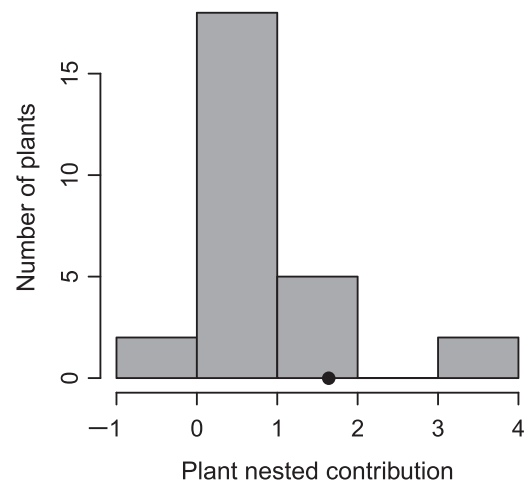

Fig. 4 Position of plant MIMs in two examples of plant-pollinator networks. (A) Plantpollinator network at Norwood Farm, Somerset, UK based on data from Pocock et al. (2012). Rectangles at the bottom (top) of the web correspond to plant (pollinator) species. Habitats to which plant species belong are represented by different rectangle and link colours, with the same colour legend as in boxplots in panels ( $B$ and $C$ ). ( $B$ and $C$ ) 
datasets had the advantage of describing not only the visits on crops and associated weeds (as done in Carvalheiro et al., 2010, 2012) but also the flower visits in field margins (Stanley, 2013) or in all managed and nonmanaged farmland habitats (Pocock et al., 2012). We assessed the position of managed and unmanaged plants in the two networks regarding degree and contribution to nestedness (Fig. 4). In Pocock et al. (2012), the only flowering crop was Medicago sativa, which was cultivated for silage. Our analyses reveal that this plant had a low degree in the network, as well as a low contribution to nestedness, contrary to what we expected (Fig. 4B and C). To the contrary, plant species in grass fields, which were managed as pasture, and in hedges or field margins, tended to occupy more central positions in the network, with high degrees and high contributions to nestedness (the plant species with highest degree and contribution to nestedness was the grassland species Ranunculus repens). In the dataset collected by Stanley (2013), the flowering crop was $B$. napus and it was one of the most generalist plant species in the network as well as one of the greatest contributors to nestedness (Fig. 4D and E). The analysis of these two datasets thus shows contrasting results regarding the position of MFC in pollination networks. Although such analyses would obviously need to be repeated on other datasets, this result suggests that plant MIMs, despite their common feature of being abundant, might have highly variable positions in plant-pollination networks depending on their floral morphology and attractiveness relative to other plants in nearby seminatural habitats. Thus, comparison of managed and nonmanaged species with similar traits would allow to better understanding the impact of management practices on species positions in networks. A recent study showed that arable lands are poor in nectar resources relatively to grasslands (Baude et al., 2016). Our results from the dataset of Pocock et al. (2012) are in agreement with this finding since plant species in grasslands seem attractive to a larger diversity of flower visitors than the crop.

Distribution of plant degrees (B) and nested contributions (C) in Norwood Farm dataset as a function of habitat types as defined in Pocock et al. (2012) (APN, arable not planted fields; C, crop; $G$, grass fields; $H$, hedges and field margins; W, woody species; WU, woodland understorey). (D) Plant-pollinator network in oilseed rape fields and bordering margins in South-East Ireland farms, based on data from Stanley (2013). Same legend as in (A), except that black rectangle and links are related to oilseed rape, while light grey rectangles and links correspond to noncultivated plants. ( $E$ and F) Distribution of plant generalism degrees $(E)$ and nested contributions $(F)$ in the network of oilseed rape fields, the black dot giving the corresponding values for oilseed rape. 


\subsection{MIMS in Plant-Pollinator Networks: Consequences for Community Dynamics}

The few existing studies, as well as our data analysis, suggest that both plant and pollinator MIMS may effectively interfere with native plant-pollinator networks (Fig. 1). In some cases, MIMS such as A. mellifera and oilseed rape occupy a central position in the networks, being characterized by high degree and a high contribution to nestedness. This position is comparable to that often found for invasive pollinator and plant species in mutualistic networks (Albrecht et al., 2014; Stouffer et al., 2014; Traveset and Richardson, 2014; Traveset et al., 2013), and have been highlighted as an important driver of eco-evolutionary feedbacks favouring trait complementarity between the two levels of a mutualistic network (for example, plants and pollinators) and increasing trait convergence within levels (Guimaraes et al., 2011). For $A$. mellifera, this similarity with invasive species is not surprising since it is considered as invasive in some parts of the world (Goulson, 2003). The observed high generalism of MIMS in networks can also be related with their potentially high abundance in ecosystems relative to wild species. Indeed, abundant species generally are more likely to be generalists in observed mutualistic networks, due to higher encounter probability (Fort et al., 2016). MIMS might thus, in some cases, increase connectance and nestedness of plant-pollinator networks as well as decrease network modularity, as has been suggested for invasive species (Albrecht et al., 2014; Stouffer et al., 2014; Traveset et al., 2013). Increased network connectance and nestedness might favour species persistence and community stability (Rohr et al., 2014; Thébault and Fontaine, 2010), but it could also decrease species diversity if competition between pollinators for resources and between plants for pollinator access is important (Benadi et al., 2012; Valdovinos et al., 2013). However, it remains unclear whether MIMS will actually modify overall network properties. While invasive species have central positions in mutualistic networks, the connectance and nestedness of invaded and noninvaded networks often do not differ, invasion leading to rearrangement of links within the network without affecting its overall structure (Traveset and Richardson, 2014; Vilà et al., 2009). Tiedeken and Stout (2015) assessed the impact of flower pulse from alien Rhododendron ponticum and found few differences between pollination networks during and after the flowering period. Only the mean generalism of the network increased after the flowering period, as most pollinators increased their diet breadth to compensate for the loss of $R$. ponticum availability. Thus, we 
might expect that MFC will have similar consequences on plant-pollinator networks, by mainly modifying link arrangements within networks during flowering rather than affecting overall network properties. The results of Stanley (2013) suggest that networks seem to be more prone to modification after the introduction of specific crops (even introduction of nonflowering crops) rather than to changes in resource abundances following mass flowering (Stanley, 2013).

Future studies will need to assess how plant-pollinator networks change depending on MIMS characteristics, and they will also need to investigate more closely the functional consequences of link rearrangements following MIMS introduction.

\section{CONCLUSION}

By reviewing the literature on the impacts of MIMS in pollination systems, we showed that such species can affect native plant-pollinator communities with consequences for ecosystem functioning. To sum up, both competition for floral resources or for pollinators and pathogen spillover, appear as the main mechanisms by which MIMS can have a negative impact on native species (Fig. 2). Further, pollinating MIMS seem also more prone to visit invasive or exotic plant species which might favour these plants at the cost of natural species (invasion meltdown). The analysis of how A. mellifera, and MFC fit into pollination networks showed that MIMS tend to be integrated in interaction networks in a way similar to invasive species, although this definitely needs further investigation (see Pantel et al., 2017 for questions relating to invasions in ecological networks).

We stress that the consequences of massive introduction of managed species should not be overlooked, even if such species are domesticated, well known and could have positive economic impact. This is particularly important for ecosystems with high biodiversity such as oceanic islands (Box 1) or protected habitats (Box 2) that should probably be preserved from MIMS, but it is also the case for anthropogenic habitat such as cities where the density of $A$. mellifera colonies is currently skyrocketing (Box 5) or agricultural landscapes where the balance between native and managed pollinators is critically needed (Box 3). Our review focused on A. mellifera, $B$. terrestris and MFC since these are currently the most widespread MIMS. However, recent practices tend to diversify the set of managed pollinator 
species with some incentive to use local species (Box 6). Other measures such as the creation of flower-rich patches within cities and agricultural habitats (Box 4) might support the functioning of the pollination systems. One should, however, be careful that such new managed species do not become victims of their own success and become the new MIMS. Indeed, while we did not discuss the case of ornamental plants here, they also could be considered as MIMS and their consequences on plant-pollinator networks needs to be addressed in the future. As an example, Garbuzov et al. (2015) have shown that the majority (77\%) of ornamental flower communities grown in urban parks in a UK city were poorly or totally unattractive to insect floral visitors, and some ornamental plants can also behave as invasive species if they spread outside of the patches they were initially sown.

As a conclusion, we argue here that practices aimed at introducing new species, be they managed pollinators or sown flowering species, should be careful in their choice of species and their methodology. We are also convinced that attention must be focused on wild species regarding conservation measures. The preservation of natural habitats, the development of agroecology (through intercropping, for example) and the generalization of friendly practices towards wild pollinators should be encouraged. Moreover, with increasing evidences of the importance of wild bees for crop pollination (Garibaldi et al., 2016), this could also be beneficial for agrosystems and prevent excessive introduction of managed pollinating species.

\section{ACKNOWLEDGEMENTS}

We would like to thank Michel Aubert and Eric Dufrêne for their contribution to an earlier literature overview (Vereecken et al., 2015) upon which the present work is partly based. We also thank Floriane Flacher for her advice on earlier versions of the draft.

\section{REFERENCES}

Abe, T., Wada, K., Kato, Y., Makino, S., Okochi, I., 2011. Alien pollinator promotes invasive mutualism in an insular pollination system. Biol. Invasions 13, 957-967.

Acosta, A.L., Giannini, T.C., Imperatriz-Fonseca, V.L., Saraiva, A.M., 2016. Worldwide alien invasion: a methodological approach to forecast the potential spread of a highly invasive pollinator. PLoS One 11, e0148295. http://dx.doi.org/10.1371/journal.pone.0148295.

Adler, V.H., Lubin, Y., Coll, M., 2014. Spillover of crop herbivores into adjacent desert habitats. Agric. Ecosyst. Environ. 193, 117-124.

Aebi, A., Vaissière, B.E., Vanengelsdorp, D., Delaplane, K.S., Roubik, D.W., Neumann, P., 2012. Back to the future: Apis versus non-Apis pollination. Trends Ecol. Evol. 27, 142-143. 
Aizen, M.A., Harder, L.D., 2009. The global stock of domesticated honeybees is growing slower than agricultural demand for pollination. Curr. Biol. 19, 915-918. http://dx. doi.org/10.1016/j.cub.2009.03.071.

Aizen, M.A., Garibaldi, L.A., Cunningham, S.A., Klein, A.M., 2008. Long-term global trends in crop yield and production reveal no current pollination shortage but increasing pollinator dependency. Curr. Biol. 18, 1572-1575. http://dx.doi.org/10.1016/ j.cub.2008.08.066.

Aizen, M.A., Morales, C.L., Vázquez, D.P., Garibaldi, L.A., Sáez, A., Harder, L.D., 2014. When mutualism goes bad: density-dependent impacts of introduced bees on plant reproduction. New Phytol. 204, 322-328. http://dx.doi.org/10.1111/nph.12924.

Albrecht, M., Duelli, P., Müller, C., Kleijn, D., Schmid, B., 2007. The Swiss agrienvironment scheme enhances pollinator diversity and plant reproductive success in nearby intensively managed farmland. J. Appl. Ecol. 44, 813-822. http://dx.doi.org/ 10.1111/j.1365-2664.2007.01306.x.

Albrecht, J., Gertrud Berens, D., Jaroszewicz, B., Selva, N., Brandl, R., Farwig, N., 2014. Correlated loss of ecosystem services in coupled mutualistic networks. Nat. Commun. 5, 3810. http://dx.doi.org/10.1038/ncomms4810.

Alton, K., Ratnieks, F.L.W., 2016. To Bee or not to Bee. Biologist 60, 12-15.

Arbetman, M.P., Meeus, I., Morales, C.L., Aizen, M.a., Smagghe, G., 2012. Alien parasite hitchhikes to Patagonia on invasive bumblebee. Biol. Invasions 15, 489-494. http://dx. doi.org/10.1007/s10530-012-0311-0.

Artz, D.R., Nault, B.A., 2011. Performance of Apis mellifera, Bombus impatiens, and Peponapis pruinosa (Hymenoptera: Apidae) as Pollinators of Pumpkin. J. Econ. Entomol. 104, 1153-1161. http://dx.doi.org/10.1603/EC10431.

Badano, E.I., Vergara, C.H., 2011. Potential negative effects of exotic honeybees on the diversity of native pollinators and yield of highland coffee plantations. Agric. For. Entomol. 13, 365-372. http://dx.doi.org/10.1111/j.1461-9563.2011.00527.x.

Banaszak-Cibicka, W., Żmihorski, M., 2012. Wild bees along an urban gradient: winners and losers. J. Insect. Conserv. 16, 331-343. http://dx.doi.org/10.1007/s10841-0119419-2.

Barthell, J.F., Frankie, G.W., Thorp, R.W., 1998. Invader effects in a community of cavity nesting megachilid bees (Hymenoptera : Megachilidae). Environ. Entomol. 27, 240-247. http://dx.doi.org/10.1093/ee/27.2.240.

Barthell, J.F., Randall, J.M., Thorp, R.W., Wenner, A.M., 2001. Promotion of seed set in yellow star-thistle by honeybees: evidence of an invasive mutualism. Ecol. Appl. 11, 1870-1883.

Bascompte, J., Jordano, P., Olesen, J.M., 2006. Asymmetric coevolutionary networks facilitate biodiversity maintenance. Science 312, 431-433.

Baude, M., Leloup, J., Suchail, S., Allard, B., Benest, D., Mériguet, J., Nunan, N., Dajoz, I., Raynaud, X., 2011. Litter inputs and plant interactions affect nectar sugar content. J. Ecol. 99, 828-837. http://dx.doi.org/10.1111/j.1365-2745.2011.01793.x.

Baude, M., Kunin, W.E., Boatman, N.D., Conyers, S., Davies, N., Gillespie, M.A.K., Morton, R.D., Smart, S.M., Memmott, J., 2016. Historical nectar assessment reveals the fall and rise of floral resources in Britain. Nature 530, 85-88. http://dx.doi.org/ 10.1038/nature16532.

Bell, D.T., Muller, C.H., 1973. Dominance of California annual grasslands by Brassica nigra. Am. Midl. Nat. 90, 227-299.

Bell, J.M., Karron, J.D., Mitchell, R.J., 2005. Interspecific competition for pollination lowers seed production and outcrossing in Mimulus ringens. Ecology 83, 762-771.

Benadi, G., Blüthgen, N., Hovestadt, T., Poethke, H.-J., 2012. Population dynamics of plant and pollinator communities: stability reconsidered. Am. Nat. 179, 157-168. http://dx. doi.org/10.1086/663685. 
Benton, T.G., Vickery, J.A., Wilson, J.D., 2003. Farmland biodiversity: is habitat heterogeneity the key? Trends Ecol. Evol. 18, 182-188.

Biesmeijer, J.C., Roberts, S.P.M., Reemer, M., Ohlemüller, R., Edwards, M., Peeters, T., Schaffers, A.P., Potts, S.G., Kleukers, R., Thomas, C.D., Settele, J., Kunin, W.E., 2006. Parallel declines in pollinators and insect-pollinated plants in Britain and the Netherlands. Science 313, 351-354. http://dx.doi.org/10.1126/science.1127863.

Biniaś, B., Gospodarek, J., Rusin, M., 2015. The effect of intercropping of broad bean (Vicia faba L.) with sweet alyssum (Lobularia maritima L.) and white mustard (Synapis alba L.) on the energy and the ability of seed germination. J. Res. Appl. Agric. Eng. 60, 11-15.

Blaauw, B.R., Isaacs, R., 2014. Flower plantings increase wild bee abundance and the pollination services provided to a pollination-dependent crop. J. Appl. Ecol. 180, 120-126. http://dx.doi.org/10.1111/1365-2664.12257.

Blackmore, L.M., Goulson, D., 2014. Evaluating the effectiveness of wildflower seed mixes for boosting floral diversity and bumblebee and hoverfly abundance in urban areas. Insect Conserv. Divers. 7, 480-484.

Blitzer, E.J., Dormann, C.F., Holzschuh, A., Klein, A.M., Rand, T.A., Tscharntke, T., 2012. Spillover of functionally important organisms between managed and natural habitats. Agric. Ecosyst. Environ. 146, 34-43. http://dx.doi.org/10.1016/j.agee.2011.09.005.

Brian, A., 1957. Differences in the flowers visited by four species of bumble-bees and their causes. J. Anim. Ecol. 26, 71-98.

Brooks, T.M., Mittermeier, R.A., da Fonseca, G.A.B., Gerlach, J., Hoffmann, M., Lamoreux, J.F., Mittermeier, C.G., Pilgrim, J.D., Rodrigues, A.S.L., 2006. Global biodiversity conservation priorities. Science 313, 58-61. http://dx.doi.org/10.1126/ science.1127609.

Burdon, J.J., Thrall, P.H., 2008. Pathogen evolution across the agro-ecological interface: implications for disease management. Evol. Appl. 1, 57-65. http://dx.doi.org/ 10.1111/j.1752-4571.2007.00005.x.

Burgos, E., Ceva, H., Perazzo, R.P.J., Devoto, M., Medan, D., Zimmermann, M., Delbue, A.M., 2007. Why nestedness in mutualistic networks? J. Theor. Biol. 249, 307-313.

Cairns, C.E., Villanueva-Gutiérrez, R., Koptur, S., Bray, D.B., 2005. Bee populations, forest disturbance, and Africanization in Mexico. Biotropica 37, 686-692. http://dx.doi.org/ 10.1111/j.1744-7429.2005.00087.x.

Cameron, S.A., Lozier, J.D., Strange, J.P., Koch, J.B., Cordes, N., Solter, L.F., Griswold, T.L., 2011. Patterns of widespread decline in North American bumblebees. Proc. Natl. Acad. Sci. U.S.A. 108, 662-667. http://dx.doi.org/10.1073/pnas.1014743108.

Cameron, S.A., Lim, H.C., Lozier, J.D., Duennes, M.A., Thorp, R., 2016. Test of the invasive pathogen hypothesis of bumble bee decline in North America. Proc. Natl. Acad. Sci. U.S.A. 113, 4386-4391. http://dx.doi.org/10.1073/pnas.1525266113.

Campbell, D.R., Motten, A.F., 1985. The mechanism of competition of pollination between two forest herbs. Ecology 66, 554-563.

Cane, J.H., Tepedino, V.J., 2016. Gauging the effect of honey bee pollen collection on native bee communities. Conserv. Lett. 53, 1-30. http://dx.doi.org/10.1111/ conl.12263.

Cane, J.H., Griswold, T., Parker, F.D., 2007. Substrates and materials used for nesting by North American Osmia bees (Hymenoptera: Apiformes: Megachilidae). Ann. Entomol. Soc. Am. 100, 350-358.

Carvalheiro, L.G., Seymour, C.L., Veldtman, R., Nicolson, S.W., 2010. Pollination services decline with distance from natural habitat even in biodiversity-rich areas. J. Appl. Ecol. 47, 810-820. http://dx.doi.org/10.1111/j.1365-2664.2010.01829.x. 
Carvalheiro, L.G., Seymour, C.L., Nicolson, S.W., Veldtman, R., 2012. Creating patches of native flowers facilitates crop pollination in large agricultural fields: mango as a case study. J. Appl. Ecol. 49, 1373-1383. http://dx.doi.org/10.1111/j.1365-2664.2012.02217.x.

Carvalheiro, L.G., Kunin, W.E., Keil, P., Aguirre-Gutiérrez, J., Ellis, W.N., Fox, R., Groom, Q., Hennekens, S., Van Landuyt, W., Maes, D., Van de Meutter, F., Michez, D., Rasmont, P., Ode, B., Potts, S.G., Reemer, M., Roberts, S.P.M., Schaminée, J., WallisDeVries, M.F., Biesmeijer, J.C., 2013. Species richness declines and biotic homogenisation have slowed down for NW-European pollinators and plants. Ecol. Lett. 16, 870-878. http://dx.doi.org/10.1111/ele.12121.

Carvalheiro, L.G., Biesmeijer, J.C., Benadi, G., Fründ, J., Stang, M., Bartomeus, I., KaiserBunbury, C.N., Baude, M., Gomes, S.I.F., Merckx, V., Baldock, K.C.R., Bennett, A.T.D., Boada, R., Bommarco, R., Cartar, R., Chacoff, N., Dänhardt, J., Dicks, L.V., Dormann, C.F., Ekroos, J., Henson, K.S.E., Holzschuh, A., Junker, R.R., Lopezaraiza-Mikel, M., Memmott, J., Montero-Castaño, A., Nelson, I.L., Petanidou, T., Power, E.F., Rundlöf, M., Smith, H.G., Stout, J.C., Temitope, K., Tscharntke, T., Tscheulin, T., Vilà, M., Kunin, W.E., 2014. The potential for indirect effects between co-flowering plants via shared pollinators depends on resource abundance, accessibility and relatedness. Ecol. Lett. 17, 1389-1399. http:// dx.doi.org/10.1111/ele.12342.

Chamberlain, S.A., Whitney, K.D., Rudgers, J.A., 2013. Proximity to agriculture alters abundance and community composition of wild sunflower mutualists and antagonists. Ecosphere 4, 96. http://dx.doi.org/10.1890/ES13-00026.1.

Chen, Y.P., Siede, R., 2007. Honeybee viruses. Adv. Virus Res. 70, 33-80.

Colla, S.R., Otterstatter, M.C., Gegear, R.J., Thomson, J.D., 2006. Plight of the bumblebee: pathogen spillover from commercial to wild populations. Biol. Conserv. 129, 461-467. http://dx.doi.org/10.1016/j.biocon.2005.11.013.

Concepcion, E.D., Moretti, M., Altermatt, F., Nobis, M.P., Obrist, M.K., 2015. Impacts of urbanisation on biodiversity: the role of species mobility, degree of specialisation and spatial scale. Oikos 124, 1571-1582. http://dx.doi.org/10.1111/oik.02166.

Crane, E., 1975. Honey: A Comprehensive Survey. Heinemann in Co-Operation with International Bee Research Association, London.

Crane, E., 1999. Recent research on the world history of beekeeping. Bee World 80, 174-186.

Cunningham, S.A., Fournier, A., Neave, M.J., Le Feuvre, D., 2016. Improving spatial arrangement of honeybee colonies to avoid pollination shortfall and depressed fruit set. J. Appl. Ecol. 53, 350-359. http://dx.doi.org/10.1111/1365-2664.12573.

Cussans, J., Goulson, D., Sanderson, R., Goffe, L., Darvill, B., Osborne, J.L., 2010. Two bee-pollinated plant species show higher seed production when grown in gardens compared to arable farmland. PLoS One 5, e11753. http://dx.doi.org/10.1371/journal. pone.0011753.

Dafni, A., Shmida, A., 1996. The possible ecological implications of the invasion of Bonlbus terrestris (L.) (Apidae) at Mt Carmel, Israel. In: Matheson, A., Buchmann, M., O' Toole, C., Westrich, P., Williams, I.H. (Eds.), The Conservation of Bees. The Linnean Society of London and the International Bee Research Association, London, pp. 84-199.

Dafni, A., Kevan, P., Gross, C.L., Goka, K., 2010. Bombus terrestris, pollinator, invasive and pest: an assessment of problems associated with its widespread introductions for commercial purposes. Appl. Entomol. Zool. 45, 101-113. http://dx.doi.org/10.1303/ aez.2010.101.

Danchin, É., Giraldeau, L.A., Valone, T.J., Wagner, R.H., 2004. Public information: from nosy neighbors to cultural evolution. Science 305 (5683), 487-491. 
Daszak, P., Cunningham, A.A., Hyatt, A.D., 2000. Emerging infectious diseases of wildlifethreats to biodiversity and human health. Science 287, 443-449.

Dawson, E.H., Chittka, L., 2014. Bumblebees (Bombus terrestris) use social information as an indicator of safety in dangerous environments. Proc. R. Soc. Lond. B 281, 20133174.

Dicks, L.V., Ashpole, J.E., Dänhardt, J., James, K., Jönsson, A., Randall, N., Showler, D.A., Smith, R.K., Turpie, S., Williams, D., Sutherland, W.J., 2014. Farmland Conservation: Evidence for the Effects of Interventions in Northern and Western Europe. Pelagic Publishing Ltd., Exeter, p. 504.

Diekötter, T., Kadoya, T., Peter, F., Wolters, V., Jauker, F., 2010. Oilseed rape crops distort plant-pollinator interactions. J. Appl. Ecol. 47, 209-214. http://dx.doi.org/10.1111/ j.1365-2664.2009.01759.x.

Dohzono, I., Yokoyama, J., 2010. Impacts of alien bees on native plant-pollinator relationships: a review with special emphasis on plant reproduction. Appl. Entomol. Zool. 45, 37-47. http://dx.doi.org/10.1303/aez.2010.37.

Dohzono, I., Kunitake, Y.K., Yokoyama, J., Goka, K., 2008. Alien bumble bee affects native plant reproduction through interactions with native bumble bees. Ecology 89, 3082-3092. http://dx.doi.org/10.1890/07-1491.1.

Donovan, B.J., 1980. Interactions between native and introduced bees in New Zealand. N. Z. J. Ecol. 3, 104-116.

Dudley, N., 2008. Guidelines for applying protected area management categories. IUCN, Gland, Switzerland, x + 86pp. Accessible at: https://cmsdata.iucn.org/downloads/ guidelines_for_applying_protected_area_management_categories.pdf.

Duelli, P., Obrist, M.K., 2003. Biodiversity indicators: the choice of values and measures. Agric. Ecosyst. Environ. 2063, 1-12.

Dupont, Y.L., Hansen, D.M., Valido, A., Olesen, J.M., 2004. Impact of introduced honeybees on native pollination interactions of the endemic Echium wildpretii (Boraginaceae) on Tenerife, Canary Islands. Biol. Conserv. 118, 301-311. http://dx.doi.org/10.1016/j. biocon.2003.09.010.

Ebeling, A., Klein, A.-M., Weisser, W.W., Tscharntke, T., 2012. Multitrophic effects of experimental changes in plant diversity on cavity-nesting bees, wasps, and their parasitoids. Oecologia 169, 453-465. http://dx.doi.org/10.1007/s00442-0112205-8.

Eilers, E.J., Kremen, C., Smith Greenleaf, S., Garber, A.K., Klein, A.-M., 2011. Contribution of pollinator-mediated crops to nutrients in the human food supply. PLoS One 6, e21363. http://dx.doi.org/10.1371/journal.pone.0021363.

Elbgami, T., Kunin, W.E., Hughes, W.O.H., Biesmeijer, J.C., 2014. The effect of proximity to a honeybee apiary on bumblebee colony fitness, development, and performance. Apidologie 45, 504-513. http://dx.doi.org/10.1007/s13592-013-0265-y.

European Commission, 2011. Our Life Insurance, Our Natural Capital: An EU Biodiversity Strategy to 2020. Brussels, Belgium.

Evison, S.E.F., Roberts, K.E., Laurenson, L., Pietravalle, S., Hui, J., Biesmeijer, J.C., Smith, J.E., Budge, G., Hughes, W.O.H., 2012. Pervasiveness of parasites in pollinators. PLoS One 7, e30641. http://dx.doi.org/10.1371/journal.pone.0030641.

Flacher, F., Raynaud, X., Hansart, A., Motard, E., Dajoz, I., 2015. Competition with windpollinated plant species alters floral traits of insect-pollinated plant species. Sci. Rep. 5, 13345. http://dx.doi.org/10.1038/srep13345.

Fontaine, C., Thébault, E., 2015. Comparing the conservatism of ecological interactions in plant-pollinator and plant-herbivore networks. Popul. Ecol. 57, 29-36. http://dx.doi. org/10.1007/s10144-014-0473-y.

Fontaine, C., Collin, C.L., Dajoz, I., 2008. Generalist foraging of pollinators: diet expansion at high density. J. Ecol. 96, 1002-1010. http://dx.doi.org/10.1111/j.1365-2745.2008. 01405.x. 
Fort, H., Vázquez, D.P., Lan, B.L., 2016. Abundance and generalisation in mutualistic networks: solving the chicken-and-egg dilemma. Ecol. Lett. 19, 4-11. http://dx.doi.org/ 10.1111/ele.12535.

Fortel, L., Henry, M., Guilbaud, L., Guirao, A.L., Kuhlmann, M., Mouret, H., Rollin, O., Vaissière, B.E., 2014. Decreasing abundance, increasing diversity and changing structure of the wild bee community (Hymenoptera: Anthophila) along an urbanization gradient. PLoS One 9, e104679. http://dx.doi.org/10.1371/journal.pone.0104679.

Fortel, L., Henry, M., Guilbaud, L., Mouret, H., Vaissière, B.E., 2016. Use of human-made nesting structures by wild bees in an urban environment. J. Insect Conserv. 20, 239-253. http://dx.doi.org/10.1007/s10841-016-9857-y.

Frankie, G., Thorp, R., Schindler, M., Hernandez, J.L., Ertter, B., Rizzardi, M.A., 2005. Ecological patterns of bees and their host ornamental flowers in two northern California cities. J. Kansas Entomol. Soc. 78, 227-246.

Fürst, M.A., McMahon, D.P., Osborne, J.L., Paxton, R.J., Brown, M.J.F., 2014. Disease associations between honeybees and bumblebees as a threat to wild pollinators. Nature 506, 364-366. http://dx.doi.org/10.1038/nature12977.

Garbuzov, M., Schürch, R., Ratnieks, F.L.W., 2015. Eating locally: dance decoding demonstrates that urban honeybees in Brighton, UK, forage mainly in the surrounding urban area. Urban Ecosys. 18, 411-418. http://dx.doi.org/10.1007/s11252-014-0403-y.

Garder, B., 1996. European Agriculture: Policies, Production, and Trade, Gardner, Brian. Routledge Publications, New York, USA. 244 pp.

Garibaldi, L.A., Steffan-Dewenter, I., Winfree, R., Aizen, M.A., Bommarco, R., Cunningham, S.A., Kremen, C., Carvalheiro, L.G., Harder, L.D., Afik, O., Bartomeus, I., Benjamin, F., Boreux, V., Cariveau, D., Chacoff, N.P., Dudenhöffer, J.H., Freitas, B.M., Ghazoul, J., Greenleaf, S., Hipólito, J., Holzschuh, A., Howlett, B., Isaacs, R., Javorek, S.K., Kennedy, C.M., Krewenka, K.M., Krishnan, S., Mandelik, Y., Mayfield, M.M., Motzke, I., Munyuli, T., Nault, B.A., Otieno, M., Petersen, J., Pisanty, G., Potts, S.G., Rader, R., Ricketts, T.H., Rundlöf, M., Seymour, C.L., Schüepp, C., Szentgyörgyi, H., Taki, H., Tscharntke, T., Vergara, C.H., Viana, B.F., Wanger, T.C., Westphal, C., Williams, N., Klein, A.M., 2013. Wild pollinators enhance fruit set of crops regardless of honeybee abundance. Science 339, 1608-1611. http://dx. doi.org/10.1126/science.1230200.

Garibaldi, L.A., Carvalheiro, L.G., Vaissiere, B.E., Gemmill-Herren, B., Hipolito, J., Freitas, B.M., Ngo, H.T., Azzu, N., Saez, A., Astrom, J., An, J., Blochtein, B., Buchori, D., Garcia, F.J.C., Oliveira da Silva, F., Devkota, K., Ribeiro, M.D.F., Freitas, L., Gaglianone, M.C., Goss, M., Irshad, M., Kasina, M., Filho, A.J.S.P., Kiill, L.H.P., Kwapong, P., Pires, C., Pires, V., Rawal, R.S., Rizali, A., Saraiva, A.M., Veldtman, R., Viana, B.F., Witter, S., Zhang, H., 2016. Mutually beneficial pollinator diversity and crop yield outcomes in small and large farms. Science 351, 388-391. http://dx.doi.org/10.1126/science.aac7287.

Garratt, M.P.D., Breeze, T.D., Jenner, N., Polce, C., Biesmeijer, J.C., Potts, S.G., 2014. Avoiding a bad apple: insect pollination enhances fruit quality and economic value. Agric. Ecosyst. Environ. 184, 34-40. http://dx.doi.org/10.1016/j.agee.2013.10.032.

Genersch, E., Yue, C., Fries, I., de Miranda, J.R., 2006. Detection of Deformed wing virus, a honeybee viral pathogen, in bumble bees (Bombus terrestris and Bombus pascuorum) with wing deformities. J. Invertebr. Pathol. 91, 61-63.

Geslin, B., Morales, C.L., 2015. New records reveal rapid geographic expansion of Bombus terrestris Linnaeus, 1758 (Hymenoptera: Apidae), an invasive species in Argentina. Check List 11, 3-5. http://dx.doi.org/10.15560/11.3.1620.

Geslin, B., Gauzens, B., Thébault, E., Dajoz, I., 2013. Plant pollinator networks along a gradient of urbanisation. PLoS One 8, e63421. http://dx.doi.org/10.1371/journal. pone.0063421. 
Geslin, B., Le Féon, V., Folschweiller, M., Flacher, F., Carmignac, D., Motard, E., Perret, S., Dajoz, I., 2016a. The proportion of impervious surfaces at the landscape scale structures wild bee assemblages in a densely populated region. Ecol. Evol. 1-17. http://dx.doi.org/ 10.1002/ece3.2374.

Geslin, B., Le Féon, V., Kuhlmann, M., Vaissière, B.E., Dajoz, I., 2016b. The bee fauna of large parks in downtown Paris, France. Ann. Soc. Entomol. Fr. 51, 487-493. http://dx. doi.org/10.1080/00379271.2016.1146632.

Geslin, B., Oddie, M., Folschweiller, M., Legras, G., Seymour, C.L., van Veen, F.J.F., Thébault, E., 2016c. Spatiotemporal changes in flying insect abundance and their functional diversity as a function of distance to natural habitats in a mass flowering crop. Agric. Ecosyst. Environ. 229, 21-29. http://dx.doi.org/10.1016/j.agee.2016. 05.010.

Giannini, T.C., Garibaldi, L.A., Acosta, A.L., Silva, J.S., Maia, K.P., Saraiva, A.M., Guimarães, P.R., Kleinert, A.M.P., 2015. Native and non-native supergeneralist bee species have different effects on plant-bee networks. PLoS One 10, e0137198. http:// dx.doi.org/10.1371/journal.pone.0137198.

Gill, R.J., Baldock, K.C.R., Brown, M.J.F., Cresswell, J.E., Dicks, L.V., Fountain, M.T., Garratt, M.P.D., Gough, L.A., Heard, M.S., Holland, J.M., Ollerton, J., Stone, G.N., Tang, C.Q., Vanbergen, A.J., Vogler, A.P., Woodward, G., Arce, A.N., Boatman, N.D., Brand-Hardy, R., Breeze, T.D., Green, M., Hartfield, C.M., O'Connor, R.S., Osborne, J.L., Phillips, J., Sutton, P.B., Potts, S.G., 2016. Protecting an ecosystem service: approaches to understanding and mitigating threats to wild insect pollinators. Adv. Ecol. Res. 53, 135-206. http://dx.doi.org/ 10.1016/bs.aecr.2015.10.007.

Gladbach, D.J., Holzschuh, A., Scherber, C., Thies, C., Dormann, C.F., Tscharntke, T., 2011. Crop-non-crop spillover: arable fields affect trophic interactions on wild plants in surrounding habitats. Oecologia 166, 433-441.

Goodale, E., Nieh, J.C., 2012. Public use of olfactory information associated with predation in two species of social bees. Anim. Behav. 84, 919-924. http://dx.doi.org/10.1016/j. anbehav.2012.07.016.

Goulson, D., 2003. Effects of introduced bees on native ecosystems. Annu. Rev. Ecol. Evol. Syst. 34, 1-26. http://dx.doi.org/10.1146/annurev.ecolsys.34.011802. 132355.

Goulson, D., Hughes, W.O.H., 2015. Mitigating the anthropogenic spread of bee parasites to protect wild pollinators. Biol. Conserv. 191, 10-19. http://dx.doi.org/10.1016/ j.biocon.2015.06.023.

Goulson, D., Sparrow, K.R., 2009. Evidence for competition between honeybees and bumblebees; effects on bumblebee worker size. J. Insect Conserv. 13, 177-181. http://dx.doi. org/10.1007/s10841-008-9140-y.

Goulson, D., Stout, J.C., Kells, A.R., 2002. Do exotic bumblebees and honeybees compete with native flower-visiting insects in Tasmania? J. Insect Conserv. 6, 179-189. http://dx. doi.org/10.1023/A:1023239221447.

Goulson, D., Nicholls, E., Botias, C., Rotheray, E.L., 2015. Bee declines driven by combined stress from parasites, pesticides, and lack of flowers. Science 347, 1255957. http://dx.doi.org/10.1126/science.1255957.

Graystock, P., Yates, K., Evison, S.E.F., Darvill, B., Goulson, D., Hughes, W.O.H., 2013a. The Trojan hives: pollinator pathogens, imported and distributed in bumblebee colonies. J. Appl. Ecol. 50, 1207-1215. http://dx.doi.org/10.1111/1365-2664.12134.

Graystock, P., Yates, K., Darvill, B., Goulson, D., Hughes, W.O.H., 2013b. Emerging dangers: deadly effects of an emergent parasite in a new pollinator host. J. Invertebr. Pathol. 114, 114-119. http://dx.doi.org/10.1016/j.jip.2013.06.005. 
Graystock, P., Goulson, D., Hughes, W.O.H., 2014. The relationship between managed bees and the prevalence of parasites in bumblebees. PeerJ 2, e522. http://dx.doi.org/ $10.7717 /$ peerj. 522 .

Graystock, P., Goulson, D., Hughes, W.O.H., 2015. Parasites in bloom: flowers aid dispersal and transmission of pollinator parasites within and between bee species. Proc. R. Soc. B 282, 20151371. http://dx.doi.org/10.1098/rspb.2015.1371.

Graystock, P., Blane, E.J., McFrederick, Q.S., Goulson, D., Hughes, W.O.H., 2016. Do managed bees drive parasite spread and emergence in wild bees? Int. J. Parasitol. Parasit. Wildl. 5, 64-75. http://dx.doi.org/10.1016/j.ijppaw.2015.10.001.

Greenleaf, S.S., Williams, N.M., Winfree, R., Kremen, C., 2007. Bee foraging ranges and their relationship to body size. Oecologia 153, 589-596. http://dx.doi.org/10.1007/ s00442-007-0752-9.

Gross, C.L., Mackay, D., 1998. Honeybees reduce fitness in the pioneer shrub Melastoma affine (Melastomataceae). Biol. Conserv. 86, 169-178.

Guimaraes Jr., P.R., Jordano, P., Thompson, J.N., 2011. Evolution and coevolution in mutualistic networks. Ecol. Lett. 14 (9), 877-885.

Guimera, R., Amaral, L.A., 2005. Functional cartography of complex metabolic networks. Nature 433, 895-900.

Haaland, C., Naisbit, R.E., Bersier, L.-F., 2011. Sown wildflower strips for insect conservation: a review. Insect Conserv. Divers. 4, 60-80.

Haddad, N., Fuchs, S., Hepburn, H.R., Radloff, S.E., 2009. Apis florea in Jordan: source of the founder population. Apidologie 40, 508-512.

Hanley, M.E., Franco, M., Dean, C.E., Franklin, E.L., Harris, H.R., Haynes, A.G., Rapson, S.R., Rowse, G., Thomas, K.C., Waterhouse, B.R., Knight, M.E., 2011. Increased bumblebee abundance along the margins of a mass flowering crop: evidence for pollinator spill-over. Oikos 120, 1618-1624. http://dx.doi.org/10.1111/j.16000706.2011.19233.x.

Hanna, C., Foote, D., Kremen, C., 2012. Short- and long-term control of Vespula pensylvanica in Hawaii by fipronil baiting. Pest Manag. Sci. 68, 1026-1033.

Hansen, D.M., Olesen, J.M., Jones, C.G., 2002. Trees, birds and bees in Mauritius: exploitative competition between introduced honeybees and endemic nectarivorous birds? J. Biogeogr. 29, 721-734.

Hardman, C.J., Norris, K., Nevard, T.D., Hughes, B., Potts, S.G., 2016. Delivery of floral resources and pollination services on farmland under three different wildlife-friendly schemes. Agric. Ecol. Environ. 220, 142-151.

Hargreaves, A.L., Harder, L.D., Johnson, S.D., 2009. Consumptive emasculation: the ecological and evolutionary consequences of pollen theft. Biol. Rev. Camb. Philos. Soc. 84, 259-276. http://dx.doi.org/10.1111/j.1469-185X.2008.00074.x.

Hegde, R.S., Miller, D.A., 1990. Allelopathy and autotoxicity in alfalfa: characterization and effects of preceding crops and residue incorporation. Crop. Sci. 30, 1255-1259.

Henry, M., Béguin, M., Requier, F., Rollin, O., Odoux, J.-F., Aupinel, P., Aptel, J., Tchamitchian, S., Decourtye, A., 2012. A common pesticide decreases foraging success and survival in honeybees. Science 336, 348-350. http://dx.doi.org/10.1126/ science. 1215039.

Herbertsson, L., Lindström, S.A.M., Rundlöf, M., Bommarco, R., Smith, H.G., 2016. Competition between managed honeybees and wild bumblebees depends on landscape context. Basic Appl. Ecol. 17, 609-616. http://dx.doi.org/10.1016/ j.baae.2016.05.001.

Herrmann, F., Westphal, C., Moritz, R.F.A., Steffan-Dewenter, I., 2007. Genetic diver- sity and mass resources promote colony size and forager densities of a social bee (Bombus pascuorum) in agricultural landscapes. Mol. Ecol. 16, 1167-1178. 
Higes, M., Martin, R., Meana, A., 2006. Nosema ceranae, a new microsporidian parasite in honeybees in Euope. J. Invertebr. Pathol. 92, 93-95. http://dx.doi.org/10.1016/j. jip.2006.02.005.

Higes, M., Martín-Hernández, R., Martínez-Salvador, A., Garrido-Bailón, E., GonzálezPorto, A.V., Meana, A., Bernal, J.L., del Noza, M.J., Bernal, J., 2010. A preliminary study of the epidemiological factors related to honeybee colony loss in Spain. Environ. Microbiol. Rep. 2, 243-250.

Hingston, A.B., McQuillan, P.B., 1998. Does the recently introduced bumblebee Bombus terrestris (Apidae) threaten Australian ecosystems? Aust. J. Ecol. 23, 539-549. http:// dx.doi.org/10.1111/j.1442-9993.1998.tb00764.x.

Hingston, A.B., McQuillan, P.B., 1999. Displacement of Tasmanian native megachilid bees by the recently introduced bumblebee Bombus terrestris (Linnaeus, 1758) (Hymenoptera: Apidae). Aust. J. Zool. 47, 59-65.

Hingston, A.B., Marsden-Smedley, J., Driscoll, D.A., Corbett, S., Fenton, J., Anderson, R., Plowman, C., Mowling, F., Jenkin, M., Matsui, K., Bonham, K.J., Ilowski, M., Mcquillan, P.B., Yaxley, B., Reid, T., Storey, D., Poole, L., Mallick, S.A., Fitzgerald, N., Kirkpatrick, J.B., Febey, J., Harwood, A.G., Michaels, K.F., Russell, M.J., Black, P.G., Emmerson, L., Visoiu, M., Morgan, J., Breen, S., Gates, S., Bantich, M.N., Desmarchelier, J.M., 2002. Extent of invasion of Tasmanian native vegetation by the exotic bumblebee Bombus terrestris (Apoidea: Apidae). Austral Ecol. 27, 162-172. http://dx.doi.org/10.1046/j.1442-9993.2002.01179.x.

Hoekstra, A.Y., Wiedmann, T.O., 2014. Humanity's unsustainable environmental footprint. Science 344, 1114-1117. http://dx.doi.org/10.1126/science.1248365.

Holzschuh, A., Dormann, C.F., Tscharntke, T., Steffan-Dewenter, I., 2011. Expansion of mass-flowering crops leads to transient pollinator dilution and reduced wild plant pollination. Proc. Biol. Sci. 278, 3444-3451. http://dx.doi.org/10.1098/rspb.2011.0268.

Holzschuh, A., Dormann, C.F., Tscharntke, T., Steffan-Dewenter, I., 2013. Mass-flowering crops enhance wild bee abundance. Oecologia 172, 477-484. http://dx.doi.org/ 10.1007/s00442-012-2515-5.

Hoyle, M., Hayter, K., Cresswell, J.E., 2007. Effect of pollinator abundance on selffertilization and gene flow: application to GM Canola. Ecol. Appl. 17, 2123-2135.

Inari, N., Nagamitsu, T., Kenta, T., Goka, K., Hiura, T., 2005. Spatial and temporal pattern of introduced Bombus terrestris abundance in Hokkaido, Japan, and its potential impact on native bumblebees. Popul. Ecol. 47, 77-82. http://dx.doi.org/10.1007/s10144-0040205-9.

Inoue, M.N., Yokoyama, J., Washitani, I., 2008. Displacement of Japanese native bumblebees by the recently introduced Bombus terrestris (L.) (Hymenoptera: Apidae). J. Insect Conserv. 12, 135-146. http://dx.doi.org/10.1007/s10841-007-9071-z.

Inouye, D.W., 1978. Resource partitioning in bumblebees-experimental studies of foraging behavior. Ecology 59, 672-678. http://dx.doi.org/10.2307/1938769.

Jauker, F., Peter, F., Wolters, V., Diekötter, T., 2012. Early reproductive benefits of massflowering crops to the solitary bee Osmia rufa outbalance post-flowering disadvantages. Basic Appl. Ecol. 13, 268-276. http://dx.doi.org/10.1016/j.baae.2012.03.010.

Jean, R.P., 2005. Quantifying a rare event: pollen theft by honeybees from bumble bees and other bees (Apoidea: Apidae, Megachilidae) foraging at flowers. J. Kansas Entomol. Soc. 78, 172-175.

Jones, R.A.C., Coutts, B.A., 2015. Spread of introduced viruses to new plants in natural ecosystems and the threat this poses to plant biodiversity. Mol. Plant Pathol. 16, 541-545. http://dx.doi.org/10.1111/mpp.12268.

Jönsson, A., Ekroos, J., Dänhardt, J., Andersson, G., Olsson, O., Smith, H.G., 2015. Sown flower strips in southern Sweden increase abundances of wild bees and hoverflies in the wider landscape. Biol. Conserv. 184, 51-58. 
Kaiser-Bunbury, C.N., Muff, S., Memmott, J., Müller, C.B., Caflisch, A., 2010. The robustness of pollination networks to the loss of species and interactions: a quantitative approach incorporating pollinator behaviour. Ecol. Lett. 13, 442-452. http://dx.doi. org/10.1111/j.1461-0248.2009.01437.x.

Kaluza, B.F., Wallace, H., Heard, T.A., Klein, A.-M., Leonhardt, S.D., 2016. Urban gardens promote bee foraging over natural habitats and plantations. Ecol. Evol. 6, 1304-1316. http://dx.doi.org/10.1002/ece3.1941.

Kato, M., Shibata, A., Yasui, T., Nagamasu, H., 1999. Impact of introduced honeybees, Apis mellifera, upon native bee communities in the Bonin (Ogasawara) Islands. Popul. Ecol. 41, 217-228. http://dx.doi.org/10.1007/s101440050025.

Kenta, T., Inari, N., Nagamitsu, T., Goka, K., Hiura, T., 2007. Commercialized European bumblebee can cause pollination disturbance: an experiment on seven native plant species in Japan. Biol. Conserv. 134, 298-309. http://dx.doi.org/10.1016/j.biocon. 2006.07.023.

Kleijn, D., Baquero, R.A., Clough, Y., Díaz, M., De Esteban, J., Fernández, F., Gabriel, D., Herzog, F., Holzschuh, A., Jöhl, R., Knop, E., Kruess, A., Marshall, E.J.P., SteffanDewenter, I., Tscharntke, T., Verhulst, J., West, T.M., Yela, J.L., 2006. Mixed biodiversity benefits of agri-environment schemes in five European countries. Ecol. Lett. 9, 243-254. http://dx.doi.org/10.1111/j.1461-0248.2005.00869.x. discussion 254-7.

Kleijn, D., Winfree, R., Bartomeus, I., Carvalheiro, L.G., Henry, M., Isaacs, R., Klein, A.M., Kremen, C., M'Gonigle, L.K., Rader, R., Ricketts, T.H., Williams, N.M., Lee Adamson, N., Ascher, J.S., Báldi, A., Batáry, P., Benjamin, F., Biesmeijer, J.C., Blitzer, E.J., Bommarco, R., Brand, M.R., Bretagnolle, V., Button, L., Cariveau, D.P., Chifflet, R., Colville, J.F., Danforth, B.N., Elle, E., Garratt, M.P.D., Herzog, F., Holzschuh, A., Howlett, B.G., Jauker, F., Jha, S., Knop, E., Krewenka, K.M., Le Féon, V., Mandelik, Y., May, E.A., Park, M.G., Pisanty, G., Reemer, M., Riedinger, V., Rollin, O., Rundlöf, M., Sardiñas, H.S., Scheper, J., Sciligo, A.R., Smith, H.G., Steffan-Dewenter, I., Thorp, R., Tscharntke, T., Verhulst, J., Viana, B.F., Vaissière, B.E., Veldtman, R., Westphal, C., Potts, S.G., 2015. Delivery of crop pollination services is an insufficient argument for wild pollinator conservation. Nat. Commun. 6, 7414. http://dx.doi.org/10.1038/ncomms8414.

Klein, A.-M., Vaissière, B.E., Cane, J.H., Steffan-Dewenter, I., Cunningham, S.A., Kremen, C., Tscharntke, T., 2007. Importance of pollinators in changing landscapes for world crops. Proc. Biol. Sci. 274, 303-313. http://dx.doi.org/10.1098/rspb.2006.3721.

Knight, M.E., Osborne, J.L., Sanderson, R.A., Hale, R.J., Martin, A.P., Goulson, D., 2009. Bumblebee nest density and the scale of available forage. Insect Conserv. Divers. 2, 116-124.

Kovács-Hostyánszki, A., Haenke, S., Batáry, P., Jauker, B., Báldi, A., Tscharntke, T., Holzschuh, A., 2013. Contrasting effects of mass-flowering crops on bee pollination of hedge plants at different spatial and temporal scales. Ecol. Appl. 23, 1938-1946.

Labreuche, J., Tosser, V., 2014. Étude de la phénologie et du butinage de cultures intermédiaires: résultats du suivi de cinq expérimentations Colloque de restitution du projet InterAPI.

Lautenbach, S., Seppelt, R., Liebscher, J., Dormann, C.F., 2012. Spatial and temporal trends of global pollination benefit. PLoS One 7, e35954. http://dx.doi.org/10.1371/journal. pone.0035954.

Le Féon, V., Schermann-Legionnet, A., Delettre, Y., Aviron, S., Billeter, R., Bugter, R., Hendrickx, F., Burel, F., 2010. Intensification of agriculture, landscape composition and wild bee communities: a large scale study in four European countries. Agric. Ecosyst. Environ. 137, 143-150. http://dx.doi.org/10.1016/j.agee.2010.01.015.

Leather, G.R., 1983. Sunflowers (Helianthus annuus) are allelopathic to weeds. Weed Sci. 31, 37-42. http://dx.doi.org/10.2307/4043564. 
Li, J., Peng, W., Wu, J., Strange, J.P., Boncristiani, H., Chen, Y., 2011. Cross-species infection of deformed wing virus poses a new threat to pollinator conservation. J. Econ. Entomol. 104, 732-739.

Lord, W.G., Nagi, S.K., 1987. Apis florea discovered in Africa. Bee World 68, 39-40.

Lye, G.C., Lepais, O., Goulson, D., 2011. Reconstructing demographic events from population genetic data: the introduction of bumblebees to New Zealand. Mol. Ecol. 20, 2888-2900. http://dx.doi.org/10.1111/j.1365-294X.2011.05139.x.

Maccagnani, B., Burgio, G., Stanisavljević, L.Ž., Maini, S., 2007. Osmia cornuta management in pear orchards. Bull. Insectol. 60, 77-82.

Mal, T.K., Lovett-Doust, J., Lovett-Doust, L., Mul-ligan, G.A., 1992. The biology of Canadian weeds. Number 100. Lythrum salicaria. Can. J. Plant Sci. 72, 1305-1330.

Markwell, T.J., Kelly, D., Duncan, K.W., 1993. Competition between honeybees (Apis mellifera) and wasps (Vespula sp.) in honeydew beech (Nothofagus solandri var. solandri) forest. N.Z. J. Ecol. 17, 85-93.

Marrero, H.J., Medan, D., Zarlavsky, G.E., Torretta, J.P., 2016. Agricultural land management negatively affects pollination service in Pampean agro-ecosystems. Agric. Ecosyst. Environ. 218, 28-32. http://dx.doi.org/10.1016/j.agee.2015.10.024.

Martinet, B., Rasmont, P., Cederberg, B., Evrard, D., Ødegaard, F., Paukkunen, J., Lecocq, T., 2015. Forward to the north: two Euro-Mediterranean bumblebee species now cross the Arctic Circle. Ann. Soc. Entomol. Fr., 1-7. http://dx.doi.org/ 10.1080/00379271.2015.1118357.

Massantini, F., Caporali, F., Zellin, G., 1977. Evidence for allelopathic control of weeds in lines of soybean. In: Proc. Eur. Weed Res. Soc. (EWRS) Symposium on the Different Methods of Weed Control and Their Integration, vol. 1, pp. 23-28.

Massol, F., Dubart, M., Calcagno, V., Cazelles, K., Jacquet, C., Kéfi, S., Gravel, D., 2017. Island biogeography of food webs. Adv. Ecol. Res. 56, 183-262.

Matsumoto, S., Abe, A., Maejima, T., 2009. Foraging behavior of Osmia cornifrons in an apple orchard. Sci. Hortic. (Amsterdam) 121, 73-79. http://dx.doi.org/10.1016/j.scienta. 2009.01.003.

Matsumura, C., Yokoyama, J., Washitani, I., 2004. Invasion status and potential ecological impacts of an invasive alien bumblebee, Bombus terrestris L. (Hymenoptera: Apidae) naturalized in Southern Hokkaido, Japan. Glob. Environ. Res. 8, 51-66.

Maun, M.A., 1977. Suppressing effect of soybeans on barnyard grass. Can. J. Plant Sci. 57, 485-490.

McKone, M., McLauchlan, K.K., Lebrun, E.G., McCall, A.C., 2001. An edge effect caused by adult corn-rootworm beetles on sunflowers in tallgrass prairie remnants. Conserv. Biol. 15, 1315-1324.

Meeus, I., Brown, M.J.F., De Graaf, D.C., Smagghe, G., 2011. Effects of invasive parasites on bumble bee declines. Conserv. Biol. 25, 662-671. http://dx.doi.org/10.1111/ j.1523-1739.2011.01707.x.

Millenium Ecosystem Assessment, 2005. Ecosystems and Human Well-Being: Synthesis. Island Press, Washington, DC.

Miller, A.E., Brosi, B.J., Magnacca, K., Daily, G.C., Pejchar, L., 2015. Pollen carried by native and nonnative bees in the large-scale reforestation of pastureland in Hawai' $i$ : implications for pollination. Pac. Sci. 69, 67-79. http://dx.doi.org/10.2984/69.1.5.

Mollot, G., Pantel, J.H., Romanuk, T.N., 2017. The effects of invasive species on the decline in species richness: a global meta-analysis. Adv. Ecol. Res. 56, 61-83.

Montalva, J., Dudley, L., Arroyo, M.K., Retamales, H., Abrahamovich, A.H., 2011. Geographic distribution and associated flora of native and introduced bumble bees (Bombus spp.) in Chile. J. Apic. Res. 50, 11-21. http://dx.doi.org/10.3896/ IBRA.1.50.1.02. 
Morales, C.L., Aizen, M.A., 2006. Invasive mutualisms and the structure of plant-pollinator interactions in the temperate forests of north-west Patagonia, Argentina. J. Ecol. 94, 171-180. http://dx.doi.org/10.1111/j.1365-2745.2005.01069.x.

Morales, C.L., Traveset, L., 2009. A meta-analysis of impacts of alien vs. native plants on pollinator visitation and reproductive success of co-flowering native plants. Ecol. Lett. 12, 716-728.

Morales, C.L., Arbetman, M.P., Cameron, S.A., Aizen, M.A., 2013. Rapid ecological replacement of a native bumble bee by invasive species. Front. Ecol. Environ. 11, 529-534. http://dx.doi.org/10.1890/120321.

Morse, R.A., 1991. Honeybees forever. Trends Ecol. Evol. 6, 337-338. http://dx.doi.org/ 10.1016/0169-5347(91)90043-W. Personal Ed.

Morse, R.A., Calderone, N.W., 2000. The value of honeybees as pollinators of U.S. crops in 2000. Bee Cult. 132, 1-19.

Muratet, A., Fontaine, B., 2015. Contrasting impacts of pesticides on butterflies and bumblebees in private gardens in France. Biol. Conserv. 182, 148-154. http://dx.doi.org/ 10.1016/j.biocon.2014.11.045.

Murray, T.E., Coffey, M.F., Kehoe, E., Horgan, F.G., 2013. Pathogen prevalence in commercially reared bumble bees and evidence of spillover in conspecific populations. Biol. Conserv. 159, 269-276. http://dx.doi.org/10.1016/j.biocon.2012.10.021.

Myers, N., Mittermeier, R.A., Mittermeier, C.G., da Fonseca, G.A.B., Kent, J., 2000. Biodiversity hotspots for conservation priorities. Nature 403, 853-858. http://dx.doi.org/ $10.1038 / 35002501$.

Nagamitsu, T., Kenta, T., Inari, N., Horita, H., Goka, K., Hiura, T., 2007. Foraging interactions between native and exotic bumblebees: enclosure experiments using native flowering plants. J. Insect Conserv. 11, 123-130. http://dx.doi.org/10.1007/s10841-006-9025-x.

Nagamitsu, T., Yamagishi, H., Kenta, T., Inari, N., Kato, E., 2009. Competitive effects of the exotic Bombus terrestris on native bumble bees revealed by a field removal experiment. Popul. Ecol. 52, 123-136. http://dx.doi.org/10.1007/s10144-009-0151-7.

Newman, E.I., Rovira, A.D., 1975. Allelopathy among some British grassland species. J. Ecol. 63, 727-737.

Nieto, A., Roberts, S.P.M., Kemp, J., Rasmont, P., Kuhlmann, M., Criado, M.G., Biesmeijer, J.C., Bogusch, P., Dathe, H.H., Rúa, P. De, 2014. European Red List of Bees. http://dx.doi.org/10.2779/77003.

Nishikawa, Y., Shimamura, T., 2016. Effects of alien invasion by Bombus terrestris L. (Apidae) on the visitation patterns of native bumblebees in coastal plants in northern Japan. J. Insect Conserv. 20, 1-14. http://dx.doi.org/10.1007/s10841-015-9841-y.

Olesen, J.M., Bascompte, J., Dupont, Y.L., Jordano, P., 2007. The modularity of pollination networks. Proc. Natl. Acad. Sci. U.S.A. 104, 19891-19896. http://dx.doi.org/10.1073/ pnas.0706375104.

Orford, K.A., Murray, P.J., Vaughan, I.P., Memmott, J., 2016. Modest enhancements to conventional grassland diversity improve the provision of pollination services. J. Appl. Ecol. 53, 906-915. http://dx.doi.org/10.1111/1365-2664.12608.

Otterstater, M.C., Thompson, J.D., 2008. Does pathogen spill-over from commercially reared bumble bee threaten wild populations? PLoS One 3 (7), e2771.

Paini, D., Roberts, J., 2005. Commercial honeybees reduce the fecundity of an Australian native bee. Biol. Conserv. 123, 103-112. http://dx.doi.org/10.1016/j.biocon.2004.11.001.

Pantel, J.H., Bohan, D.A., Calcagno, V., David, P., Duyck, P.-F., Kamenova, S., Loeuille, N., Mollot, G., Romanuk, T.N., Thébault, E., Tixier, P., Massol, F., 2017. 14 questions for invasion in ecological networks. Adv. Ecol. Res. 56, 293-340.

Pauly, A., Hora, Z.A., 2013. Apini and Meliponini from Ethiopia (Hymenoptera: Apoidea: Apidae: Apinae). Belg. J. Entomol. 16, 1-36. 
Perrard, A., Haxaire, J., Rortais, A., Villemant, C., 2009. Observations on the colony activity of the Asian hornet Vespa velutina Lepeletier 1836 (Hymenoptera: Vespidae: Vespinae) in France. Ann. Soc. Entomol. Fr. 45, 119-127. http://dx.doi.org/10.1080/ 00379271.2009 .10697595$.

Pitts-Singer, T.L., Bosch, J., 2010. Nest establishment, pollination efficiency, and reproductive success of Megachile rotundata (Hymenoptera: Megachilidae) in relation to resource availability in field enclosures. Environ. Entomol. 39, 149-158. http://dx.doi.org/ 10.1603/EN09077.

Pitts-Singer, T.L., Cane, J.H., 2011. The alfalfa leafcutting bee, Megachile rotundata: the world's most intensively managed solitary bee. Annu. Rev. Entomol. 56, 221-237. http://dx.doi.org/10.1146/annurev-ento-120709-144836.

Pocock, M.J.O., Evans, D.M., Memmott, J., 2012. The robustness and restoration of a network of ecological networks. Science 335, 973-977. http://dx.doi.org/10.1126/ science.1214915.

Potts, S.G., Petanidou, T., Roberts, S., O’Toole, C., Hulbert, A., Willmer, P., 2006. Plantpollinator biodiversity and pollination services in a complex Mediterranean landscape. Biol. Conserv. 129, 519-529. http://dx.doi.org/10.1016/j.biocon.2005.11.019.

Potts, S.G., Biesmeijer, J.C., Kremen, C., Neumann, P., Schweiger, O., Kunin, W.E., 2010. Global pollinator declines: trends, impacts and drivers. Trends Ecol. Evol. 25, 345-353. http://dx.doi.org/10.1016/j.tree.2010.01.007.

Power, A.G., Mitchell, C.E., 2004. Pathogen spillover in disease epidemics. Am. Nat. 164, S79-S89.

Rader, R., Howlett, B.G., Cunningham, S.A., Westcott, D.A., Newstrom-Lloyd, L.E., Walker, M.K., Teulon, D.A.J., Edwards, W., 2009. Alternative pollinator taxa are equally efficient but not as effective as the honeybee in a mass flowering crop. J. Appl. Ecol. 46, 1080-1087. http://dx.doi.org/10.1111/j.1365-2664.2009.01700.x.

Rader, R., Bartomeus, I., Garibaldi, L.A., Garratt, M.P.D., Howlett, B.G., Winfree, R., Cunningham, S.A., Mayfield, M.M., Arthur, A.D., Andersson, G.K.S., Bommarco, R., Brittain, C., Carvalheiro, L.G., Chacoff, N.P., Entling, M.H., Foully, B., Freitas, B.M., Gemmill-Herren, B., Ghazoul, J., Griffin, S.R., Gross, C.L., Herbertsson, L., Herzog, F., Hipólito, J., Jaggar, S., Jauker, F., Klein, A.-M., Kleijn, D., Krishnan, S., Lemos, C.Q., Lindström, S.A.M., Mandelik, Y., Monteiro, V.M., Nelson, W., Nilsson, L., Pattemore, D.E., de O. Pereira, N., Pisanty, G., Potts, S.G., Reemer, M., Rundlöf, M., Sheffield, C.S., Scheper, J., Schüepp, C., Smith, H.G., Stanley, D.A., Stout, J.C., Szentgyörgyi, H., Taki, H., Vergara, C.H., Viana, B.F., Woyciechowski, M., 2015. Non-bee insects are important contributors to global crop pollination. Proc. Natl. Acad. Sci. U.S.A. 113, 146-151. http://dx.doi.org/10.1073/pnas.1517092112.

Ramirez, N., Brito, Y., 1992. Pollination biology in a palm swamp community in the Venezuelan central plains. Bot. J. Linn. Soc. 110, 277-302.

Ramírez, F., Davenport, T.L., 2013. Apple pollination: a review. Sci. Hortic. 162, 188-203. http://dx.doi.org/10.1016/j.scienta.2013.08.007.

Rand, T.A., Tylianakis, J.M., Tscharntke, T., 2006. Spillover edge effects: the dispersal of agriculturally subsidized insect natural enemies into adjacent natural habitats. Ecol. Lett. 9, 603-614.

Rathcke, B., 1983. Competition and facilitation among plants for pollination. In: Real, L. (Ed.), Pollination Biol. Academic Press, Orlando, FL, pp. 305-329.

Rawat, L.S., Narwal, S.S., Kadiyan, H.S., Maikhuri, R.K., Negi, V.S., 2012. Allelopathic effects of sunflower on seed germination and seedling growth of Trianthema portulacastrum. Allelopath. J. 30, 11-21.

Requier, F., Odoux, J.F., Tamic, T., Moreau, N., Henry, M., Decourtye, A., Bretagnolle, V., 2015. Honeybee diet in intensive farmland habitats reveals an 
unexpectedly high flower richness and a major role of weeds. Ecol. Appl. 25, 881-890. http://dx.doi.org/10.1890/14-1011.1.

Rice, E.L., 1984. Allelopathy, second ed. Academic Press Inc., Orlando, FL.

Ricketts, T.H., Regetz, J., Steffan-Dewenter, I., Cunningham, S.A., Kremen, C., Bogdanski, A., Gemmill-Herren, B., Greenleaf, S.S., Klein, A.M., Mayfield, M.M., Morandin, L.A., Ochieng', A., Potts, S.G., Viana, B.F., 2008. Landscape effects on crop pollination services: are there general patterns? Ecol. Lett. 11, 499-515. http://dx.doi. org/10.1111/j.1461-0248.2008.01157.x.

Rohr, R.P., Saavedra, S., Bascompte, J., 2014. On the structural stability of mutualistic systems. Science 345, 416-425.

Rollin, O., Decourtye, A., 2015. Etudes des variations temporelles des populations d'abeilles melliferes et des communautés d'abeilles sauvages selon divers contextes paysagers-Test de l'hypothèse d'une interaction compétitive entre l'espèce Apis mellifera et les abeilles sauvages non-Apis (Compte rendu). ITSAP-Institut de l'Abeille.

Rollin, O., Bretagnolle, V., Decourtye, A., Aptel, J., Michel, N., Vaissière, B.E., Henry, M., 2013. Differences of floral resource use between honeybees and wild bees in an intensive farming system. Agric. Ecosyst. Environ. 179, 78-86. http://dx.doi.org/10.1016/ j.agee.2013.07.007.

Rollin, O., Bretagnolle, V., Fortel, L., Guilbaud, L., Henry, M., 2015. Habitat, spatial and temporal drivers of diversity patterns in a wild bee assemblage. Biodivers. Conserv. 24, 1195. http://dx.doi.org/10.1007/s10531-014-0852-x.

Roubi, D.W., Villanueva-Guttiérez, R., 2009. Invasive Africanized honeybee impact on native solitary bees: a pollen resource and trap nest analysis. Biol. J. Linn. Soc. 98, 152-160.

Roubik, D.W., 1978. Competitive interactions between neotropical pollinators and africanized honeybees. Science 201, 1030-1032. http://dx.doi.org/10.1126/science.201. 4360.1030 .

Ruttner, F., 1988. Biogeography and Taxonomy of Honeybees. Springer, Berlin, Germany, p. 284.

Saavedra, S., Stouffer, D., Uzzi, B., Bascompte, J., 2011. Strong contributors to network persistence are the most vulnerable to extinction. Nature 478, 233-235.

Sáez, A., Morales, C.L., Ramos, L., Aizen, M.A., 2014. Extremely frequent bee visits increase pollen deposition but reduce drupelet set in raspberry. J. Appl. Ecol. 51, 1603-1612. http://dx.doi.org/10.1111/1365-2664.12325.

Sanguinetti, A., Singer, R.B., 2014. Invasive bees promote high reproductive success in Andean orchids. Biol. Conserv. 175, 10-20. http://dx.doi.org/10.1016/j.biocon.2014.04.011.

Santos, G.M., Aguiar, C.M., Genini, J., Martins, C.F., Zanella, F.C., Mello, M.A., 2012. Invasive Africanized honeybees change the structure of native pollination networks in Brazil. Biol. Inv. 14, 2369-2378.

Sauve, A.M.C., Thébault, E., Pocock, M.J., Fontaine, C., 2016. How plants connect pollination and herbivory networks and their contribution to community stability. Ecology 97, 908-917.

Sax, D.F., Gaines, S.D., 2008. Species invasions and extinction: the future of native biodiversity on islands. Proc. Natl. Acad. Sci. U.S.A. 105, 11 490-11 497. http://dx.doi.org/ $10.1073 /$ pnas.0710824105.

Schaffer, W.M., Zeh, D.W., Buchmann, S.L., Kleinhans, S., Valentine Schaffer, M., Antrim, J., 1983. Competition for nectar between introduced honeybees and native North American bees and ants. Ecology 64, 564-577.

Schmid-Hempel, R., Eckhardt, M., Goulson, D., Heinzmann, D., Lange, C., Plischuk, S., Escudero, L.R., Salathé, R., Scriven, J.J., Schmid-Hempel, P., 2014. The invasion of southern South America by imported bumblebees and associated parasites. J. Anim. Ecol. 83, 823-837. http://dx.doi.org/10.1111/1365-2656.12185. 
Seeley, T.D., 1985. Honeybee Ecology. Princeton University Press, Princeton, NJ.

Senapathi, D., Carvalheiro, L.G., Biesmeijer, J.C., Dodson, C., Evans, R.L., McKerchar, M., Morton, R.D., Moss, E.D., Roberts, S.P.M., Kunin, W.E., Potts, S.G., 2015. The impact of over 80 years of land cover changes on bee and wasp pollinator communities in England. Proc. R. Soc. B Biol. Sci. 282, 20150294. http://dx. doi.org/10.1098/rspb.2015.0294.

Shavit, O., Dafni, A., Ne'eman, G., 2009. Competition between honeybees (Apis mellifera) and native solitary bees in the Mediterranean region of Israel-implications for conservation. Isr. J. Plant Sci. 57, 171-183. http://dx.doi.org/10.1560/IJPS.57.3.171.

Sheffield, C.S., 2014. Pollination, seed set and fruit quality in apple: studies with Osmia lignaria (Hymenoptera: Megachilidae) in the Annapolis valley, Nova Scotia, Canada. J. Pollinat. Ecol. 12, 120-128.

Sheppard, W.S., Meixner, M.D., 2003. Apis mellifera pomonella, a new honeybee subspecies from Central Asia. Apidologie 34, 367-375.

Slaa, E.J., Sánchez Chaves, L.A., Malagodi-Braga, K.S., Hofstede, F.E., 2006. Stingless bees in applied pollination: practice and perspectives. Apidologie 37, 293-315. http://dx.doi. org/10.1051/apido:2006022.

Spiesman, B.J., Gratton, C., 2016. Flexible foraging shapes the topology of plantpollinator interaction networks. Ecology 97, 1431-1441. http://dx.doi.org/10.1890/ 15-1735.1.

Squires, S.E., Hermanutz, L., Dixon, P.L., 2009. Agricultural insect pest compromises survival of two endemic Braya (Brassicaceae). Biol. Conserv. 142, 203-211.

Stanley, D.A., 2013. Pollinators and pollination in changing agricultural landscapes; investigating the impacts of bioenergy crops. Thesis, Trinity College Dublin.

Stanley, D.A., Stout, J.C., 2013. Quantifying the impacts of bioenergy crops on pollinating insect abundance and diversity: a field-scale evaluation reveals taxon-specific responses. J. Appl. Ecol. 50, 335-344.

Stanley, D.A., Stout, J.C., 2014. Pollinator sharing between mass-flowering oilseed rape and co-flowering wild plants: implications for wild plant pollination. Plant Ecol. 215, 315-325.

Steffan-Dewenter, I., Kuhn, A., 2003. Honeybee foraging in differentially structured landscapes. Proc. R. Soc. Lond. B 270, 569-575.

Steffan-Dewenter, I., Schiele, S., 2008. Do resources or natural enemies drive bee population dynamics in fragmented habitats? Ecology 89, 1375-1387.

Steffan-dewenter, I., Tscharntke, T., 2000. Resource overlap and possible competition between honeybees and wild bees in central Europe. Oecologia 122, 288-296.

Steffan-Dewenter, I., Tscharntke, T., 2001. Succession of bee communities on fallows. Ecography 24, 83-93.

Stelzer, R.J., Chittka, L., 2010. Bumblebee foraging rhythms under the midnight sun measured with radiofrequency identification. BMC Biol. 8, 93. http://dx.doi.org/ 10.1186/1741-7007-8-93.

Stern, R.A., Goldway, M., Zisovich, A.H., Shafir, S., Dag, A., 2004. Sequential introduction of honeybee colonies increases cross-pollination, fruit-set and yield of "Spadona" pear (Pyrus communis L.). J. Hortic. Sci. Biotechnol. 79, 652-658.

Stouffer, D.B., Cirtwill, A.R., Bascompte, J., 2014. How exotic plants integrate into pollination networks. J. Ecol. 102, 1442-1450. http://dx.doi.org/10.1111/1365-2745.12310.

Stout, J.C., Morales, C.L., 2009. Ecological impacts of invasive alien species on bees*. Apidologie 40, 388-409. http://dx.doi.org/10.1051/apido/2009023.

Stout, J.C., Kells, A.R., Goulson, D., 2002. Pollination of the invasive exotic shrub Lupinus arboreus (Fabaceae) by introduced bees in Tasmania. Biol. Conserv. 106, 425-434. http:// dx.doi.org/10.1016/S0006-3207(02)00046-0. 
Sugiura, S., 2016. Impacts of introduced species on the biota of an oceanic archipelago: the relative importance of competitive and trophic interactions. Ecol. Res. 31, 155-164. http://dx.doi.org/10.1007/s11284-016-1336-0.

Thébault, E., Fontaine, C., 2010. Stability of ecological communities and the architecture of mutualistic and trophic networks. Science 329, 853-856. http://dx.doi.org/10.1126/ science.1188321.

Thomson, D., 2004. Competitive interactions between the invasive European honeybee and native bumble bees. Ecology 85, 458-470. http://dx.doi.org/10.1890/02-0626.

Thomson, D.M., 2016. Local bumble bee decline linked to recovery of honey bees, drought effects on floral resources. Ecol. Lett. 19, 1247-1255. http://dx.doi.org/10.1111/ ele.12659.

Thorp, R.W., 1996. Resource overlap among native and introduced bees in California. In: Matheson, A., Buchmann, S.L., O’Toole, C., Westrich, P., Williams, I.H. (Eds.), The Conservation of Bees. Academic Press, London, pp. 134-152.

Tiedeken, E.J., Stout, J.C., 2015. Insect-flower interaction network structure is resilient to a temporary pulse of floral resources from invasive Rhododendron ponticum. PLoS One 10, e0119733. http://dx.doi.org/10.1371/journal.pone.0119733.

Torné-Noguera, A., Rodrigo, A., Osorio, S., Bosch, J., 2015. Collateral effects of beekeeping: impacts on pollen-nectar resources and wild bee communities. Basic Appl. Ecol. 17, 199-209. http://dx.doi.org/10.1016/j.baae.2015.11.004.

Traveset, A., Richardson, D.M., 2006. Biological invasions as disruptors of plant reproductive mutualisms. Trends Ecol. Evol. 21, 208-216. http://dx.doi.org/10.1016/ j.tree.2006.01.006.

Traveset, A., Richardson, D.M., 2011. Mutualisms: key drivers of invasions ... key casualties of invasions. In: Richardson, D.M. (Ed.), Fifty Years of Invasion Ecology: The Legacy of Charles Elton. Wiley-Blackwell, Oxford, UK, pp. 143-160. http://dx.doi.org/ 10.1002/9781444329988.ch12.

Traveset, A., Richardson, D.M., 2014. Mutualistic interactions and biological invasions. Annu. Rev. Ecol. Evol. Syst. 45, 89-113. http://dx.doi.org/10.1146/annurev-ecolsys$120213-091857$.

Traveset, A., Heleno, R., Chamorro, S., Vargas, P., McMullen, C.K., Castro-Urgal, R., Nogales, M., Herrera, H.W., Olesen, J.M., 2013. Invaders of pollination networks in the Galapagos Islands: emergence of novel communities. Proc. R. Soc. B Biol. Sci. 280, 20123040. http://dx.doi.org/10.1098/rspb.2012.3040.

Tscharntke, T., Klein, A.M., Kruess, A., Steffan-Dewenter, I., Thies, C., 2005. Landscape perspectives on agricultural intensification and biodiversity-ecosystem service management. Ecol. Lett. 8, 857-874. http://dx.doi.org/10.1111/j.1461-0248.2005.00782.x.

Tschumi, M., Albrecht, M., Collatz, J., Dubsky, V., Entling, M.H., Najar-Rodriguez, A.J., Jacot, K., 2016. Tailored flower strips promote natural enemy biodiversity and pest control in potato crops. J. Appl. Ecol. 53, 1169-1176. http://dx.doi.org/10.1111/13652664.12653.

Turk, M.A., Tawaha, A.M., 2003. Allelopathic effect of black mustard (Brassica nigra L.) on germination and growth of wild oat (Avena fatua L.). Crop Prot. 22, 673-677. http://dx. doi.org/10.1016/S0261-2194(02)00241-7.

Tylianakis, J.M., 2008. Understanding the web of life: the birds, the bees, and sex with aliens. PLoS Biol. 6, 0224-0228. http://dx.doi.org/10.1371/journal.pbio.0060047.

Tylianakis, J.M., Didham, R.K., Bascompte, J., Wardle, D.A., 2008. Global change and species interactions in terrestrial ecosystems. Ecol. Lett. 11, 1351-1363. http://dx.doi.org/ 10.1111/j.1461-0248.2008.01250.x.

Tylianakis, J.M., Laliberté, E., Nielsen, A., Bascompte, J., 2010. Conservation of species interaction networks. Biol. Conserv. 143, 2270-2279. http://dx.doi.org/10.1016/ j.biocon.2009.12.004. 
Valdovinos, F.S., Moisset De Espanes, P., Flores, J.D., Ramos-Jiliberto, R., 2013. Adaptive foraging allows the maintenance of biodiversity of pollination networks. Oikos 122, 907-917.

Van Engelsdorp, D., Meixner, M.D., 2010. A historical review of managed honeybee populations in Europe and the United States and the factors that may affect them. J. Invertebr. Pathol. 103, S80-S95. http://dx.doi.org/10.1016/j.jip.2009.06.011.

Vanbergen, A.J., 2013. Threats to an ecosystem service: pressures on pollinators. Front. Ecol. Environ. 11, 251-259. http://dx.doi.org/10.1890/120126.

Vaughton, G., 1996. Pollination disruption by European honeybees in the Australian birdpollinated shrub Grevillea barklyana (Proteaceae). Plant Syst. Evol. 200, 89-100.

Vázquez, D.P., Aizen, M.A., 2004. Asymmetric specialization: a pervasive feature of plantpollinator interactions. Ecology 85, 1251-1257.

Velthuis, H.H.W., Van Doorn, A., 2006. A century of advances in bumblebee domestication and the economic and environmental aspects of its commercialization for pollination. Apidologie 37, 421-451. http://dx.doi.org/10.1051/apido.

Vereecken, N.J., Dufrêne, E., Aubert, M., 2015. Sur la coexistence entre l'abeille domestique et les abeilles sauvages. Rapport de synthèse sur les risques liés à l'introduction de ruches de l'abeille domestique (Apis mellifera) vis-à-vis des abeilles sauvages et de la flore. Observatoire des Abeilles (OA).

Vilà, M., Bartomeus, I., Dietzsch, A.C., Petanidou, T., Steffan-Dewenter, I., Stout, J.C., Tscheulin, T., 2009. Invasive plant integration into native plant-pollinator networks across Europe. Proc. Biol. Sci. 276, 3887-3893. http://dx.doi.org/10.1098/rspb. 2009.1076.

Villemant, C., Haxaire, J., Streito, J.C., 2006. Premier bilan de l'invasion de Vespa velutina Lepeletier en France (Hymenoptera, Vespidae). Bull. Soc. Entomol. Fr. 111, 535-538.

Villemant, C., Barbet-Massin, M., Perrard, A., Muller, F., Gargominy, O., Jiguet, F., Rome, Q., 2011a. Predicting the invasion risk by the alien bee-hawking Yellowlegged hornet Vespa velutina nigrithorax across Europe and other continents with niche models. Biol. Conserv. 144, 2142-2150. http://dx.doi.org/10.1016/j.biocon. 2011.04.009.

Villemant, C., Muller, F., Haubois, S., 2011b. Bilan des travaux (MNHN et IRBI) sur l'invasion en France de Vespa velutina, le frelon asiatique predateur d'abeilles. In: Barbançon, J.-M, L'Hostis, M. (Eds.), Journée Scientifique Apicole JSA, Arles, 11 février 2011. ONIRIS-FNOSAD, Nantes, pp. 3-12.

Walther-Hellwig, K., Fokul, G., Frankl, R., Buchler, R., Ekschmitt, K., Wolters, V., 2006. Increased density of honeybee colonies affects foraging bumblebees. Apidologie 37, 517-532. http://dx.doi.org/10.1051/apido:2006035.

Watts, S., Ovalle, D.H., Herrera, M.M., Ollerton, J., 2012. Pollinator effectiveness of native and non-native flower visitors to an apparently generalist Andean shrub, Duranta mandonii (Verbenaceae). Plant Species Biol. 27, 147-158. http://dx.doi.org/10.1111/ j.1442-1984.2011.00337.x.

Westphal, C., Steffan-Dewenter, I., Tscharntke, T., 2003. Mass flowering crops enhance pollinator densities at a landscape scale. Ecol. Lett. 6, 961-965. http://dx.doi.org/ 10.1046/j.1461-0248.2003.00523.x.

Westphal, C., Steffan-Dewenter, I., Tscharntke, T., 2006. Foraging trip duration of bumblebees in relation to landscape-wide resource availability. Ecol. Entomol. 31, 389-394. http://dx.doi.org/10.1111/j.1365-2311.2006.00801.x.

Westphal, C., Steffan-Dewenter, I., Tscharntke, T., 2009. Mass flowering oilseed rape improves early colony growth but not sexual reproduction of bumblebees. J. Appl. Ecol. 46, 187-193. http://dx.doi.org/10.1111/j.1365-2664.2008.01580.x.

Williams, I.H., 1994. The dependence of crop production within the European Union on pollination by honeybees. Agric. Zool. Rev. 6, 229-257. 
Williams, P.H., An, J., Brown, M.J.F., Carolan, J.C., Goulson, D., Huang, J., Ito, M., 2012. Cryptic bumblebee species: consequences for conservation and the trade in greenhouse pollinators. PLoS One 7, 1-8. http://dx.doi.org/10.1371/journal.pone.0032992.

Zhang, H., Huang, J., Williams, P.H., Vaissière, B.E., Zhou, Z., Gai, Q., Dong, J., An, J., 2015. Managed bumblebees outperform honeybees in increasing peach fruit set in China: different limiting processes with different pollinators. PLoS One 10, e0121143. http:// dx.doi.org/10.1371/journal.pone.0121143.

Zurbuchen, A., Landert, L., Klaiber, J., Mueller, A., Hein, S., Dorn, S., 2010. Maximum foraging ranges in solitary bees: only few individuals have the capability to cover long foraging distances. Biol. Conserv. 143, 669-676. 